\title{
Antagonism of Human Formyl Peptide Receptor 1 with Natural Compounds and their
}

\section{Synthetic Derivatives}

\author{
Igor A. Schepetkin ${ }^{1, \dagger}$, Andrei I. Khlebnikov ${ }^{2, \dagger}$, Liliya N. Kirpotina ${ }^{1}$, and Mark T. Quinn ${ }^{1}$ \\ ${ }^{1}$ Department of Microbiology and Immunology, Montana State University, Bozeman, MT 59717, \\ United States \\ ${ }^{2}$ Department of Biotechnology and Organic Chemistry, Tomsk Polytechnic University, Tomsk \\ 634050, Russia and Department of Chemistry, Altai State Technical University, Barnaul, Russia.
}

$\dagger$ These authors contributed equally to this work

\section{Address for Correspondence:}

Mark T Quinn, Ph.D.

Department of Microbiology and Immunology

Montana State University

Bozeman, MT 59717

Phone: 1-406-994-4707

Fax: 1-406-994-4303

Email: mquinn@montana.edu 


\begin{abstract}
Formyl peptide receptor 1 (FPR1) regulates a wide variety of neutrophil functional responses and plays an important role in inflammation and the pathogenesis of various diseases. To date, a variety of natural and synthetic molecules have been identified as FPR1 ligands. Here, we review current knowledge on natural products and natural product-inspired smallmolecules reported to antagonize and/or inhibit the FPR1-mediated responses. Based on this literature, additional screening of selected commercially available natural compounds for their ability to inhibit $f$ MLF-induced $\mathrm{Ca}^{2+}$ mobilization in human neutrophils and FPR1 transfected HL-60 cells, and pharmacophore modeling, natural products with potential as FPR1 antagonists are considered and discussed in this review. The identification and characterization of natural products that antagonize FPR1 activity may have potential for the development of novel therapeutics to limit or alter the outcome of inflammatory processes.
\end{abstract}

Keywords: Natural compound, formyl peptide receptor 1, neutrophil, receptor antagonist, superoxide anion radical, neutrophil elastase, $\mathrm{Ca}^{2+}$ flux, molecular modeling

\begin{abstract}
Abbreviations:
Cs, Cyclosporine; CHIPS, chemotaxis inhibitory protein of Staphylococcus aureus; FPR, formyl peptide receptor; GPCR, G-protein coupled receptor; HNE, human neutrophil elastase; PAF, platelet activating factor; PMA, phorbol-12-myristate-13-acetate; ROS, reactive oxygen species; SAR, structure-activity relationship; FITC, fluorescein isothiocyanate; NDGA, nordihydroguaiaretic acid.
\end{abstract}




\section{Introduction}

Forty years ago, Schiffmann et al. [1] reported that $N$-formylated peptides are potent chemotactic agents for human neutrophils. Further study of the biological targets of formylated peptides led to the identification and subsequent cloning of human formyl peptide receptor 1 (FPR1) $[2,3]$. Two other relatively conserved low-affinity fMLF receptors, now termed as FPR2 and FPR3, were subsequently cloned (reviewed in [4]). FPR1 is a key regulator of the inflammatory environment. However, the expression of FPRs in various nonphagocytic cells suggests that these receptors also participate in functions other than innate immunity and may represent unique targets for therapeutic drug design [5-7]. Such drugs may have the potential to treat many inflammatory diseases, including rheumatoid arthritis, asthma, other auto-immune diseases, and stimulate wound healing [6, 8-10].

Since FPRs represent potentially important therapeutic targets, much attention has been focused over the last two decades on the identification of natural and synthetic compounds that interact with these receptors and/or interfere with FPR-dependent pathways. To date, several reviews summarizing the research efforts on FPR1 and FPR2 agonists, including natural ligands, have been published [4, 11-16]. However, less attention has focused on natural FPR1 antagonists.

Natural products traditionally have played an important role in drug discovery and were the basis of most early medicines [17]. The potential of natural products as sources for new drugs is still largely unexplored, and only a small fraction of the products present in existing plants, fungi, microorganisms, and animals have been investigated so far. Previously, we reported that many FPR1 antagonists contain $\mathrm{OH}$ groups, which can serve as H-bond donors and/or acceptors upon binding to the receptor, and that this feature is much more characteristic of FPR1 antagonists than agonists [16]. Because natural compounds in general incorporate more 
oxygen atoms than synthetic compounds and drugs [18], this feature makes them attractive for screening as FPR1 antagonists. Furthermore, natural products contain more fused rings, but fewer rotatable bonds than synthetic medicinal compounds [18], and this particular feature is also characteristic of FPR1 antagonists [16, 19].

FPR1 activation stimulates multiple signal transduction pathways responsible for various neutrophil functions, such as adhesion, chemotaxis, phagocytosis, exocytosis of secretory granules, and superoxide anion radical $\left(\mathrm{O}_{2}^{--}\right)$production, which contribute to the physiological inflammatory response associated with bacterial infection and tissue damage (reviewed in [4, 20, 21]). The main molecular events and mediators involved in FPR1 activation are summarized in Figure 1. The FPR1 ligand $f$ MLF is known to activate phospholipases $\mathrm{C}(\mathrm{PLC})$ and $\mathrm{A}_{2}\left(\mathrm{PLA}_{2}\right)$ and release of intracellular $\mathrm{Ca}^{2+}$ stores. The second messengers resulting from FPR1 activation regulate various intracellular kinases, including phosphatidylinositol-3-kinase (PI3K), protein kinase $\mathrm{C}(\mathrm{PKC})$, and mitogen-activated protein (MAP) kinases p38 and extracellular signal related kinase 1 and 2 (ERK 1/2). Activation of the FPR1 stimulates an additional protein kinase C-independent pathway through the Src-related tyrosine kinase, Lyn, in human neutrophils [22]. Likewise, downstream activation of Rho GTPases, particularly Rac1 and Rac2, plays a key role in neutrophil NADPH oxidase assembly, chemotaxis, and degranulation [23]. Activation of these signal-transduction pathways is known to be responsible for the various biochemical responses that contribute to physiological defense against pathogens and the inflammatory response to cellular damage. Although the intrinsic functional redundancy in the chemoattractant/chemokine system may make blocking a single receptor problematic as a therapeutic approach [24], various approaches to inhibit the FPR1 signaling have nevertheless been considered for therapeutic development. For example, natural compounds have been evaluated for their ability to inhibit leukocyte chemotaxis, reactive oxygen species (ROS) 
production, and human neutrophil elastase (HNE) release by targeting $f$ MLF-induced signaling cascades. Since excess NADPH-oxidase generated ROS, HNE, and other neutrophil-derived proteases can promote inflammation and numerous pathological conditions [25-27], this approach could have significant clinical benefit if effective and specific inhibitors were identified.

Of particular interest is the possibility that FPR1 antagonists that can transiently inhibit neutrophil responses to formylated peptides could be therapeutic agents in the treatment of inflammatory diseases. In efforts to discover new anti-inflammatory agents from natural sources, inhibitory activity of several hundred compounds derived from bacteria, higher plants, algae, and marine corals have been screened for their ability to inhibit $f$ MLF-induced functional responses in neutrophils. These products include a wide range of compound classes from peptides to secondary metabolites, such as flavonoids, coumarins, quinones, naphtalenones, lignans, terpenoids (sesquiterpene lactones, diterpenes, triterpenes), steroids, alkaloids and other compounds. Some of these compounds blocked FPR1 directly, while others inhibited downstream $f$ MLF-induced pathways.

In this review, we will summarize the outcome of previous screening efforts and reconsider these studies with a specific focus on FPR1 antagonists. For some of these previously reported natural compounds, we also conducted additional screening of analogs and similar compounds for their ability to antagonize FPR1 activation by $f$ MLF in human neutrophils and FPR1-transfected cells. Because a high possibility exists that compounds capable of inhibiting $f$ MLF signaling may target FPR1 as one of their molecular mechanisms of action, we also used pharmacophore modeling and molecular docking studies to predict how well various natural compounds fit the FPR1 antagonist pharmacophore and their potential for binding to FPR1. 


\section{Natural peptides and their derivatives as FPR1 antagonists}

\subsection{Cyclosporines and other cyclic peptides}

The hydrophobic cyclic peptides, cyclosporine A (CsA) and $\mathrm{H} \mathrm{CsH}$ ), are among most potent and receptor-specific FPR1 antagonists described so far [28, 29]. Both cyclosporines were first isolated as undecapeptides from the fungus Tolypocladium inflatum. Although CsA and $\mathrm{CsH}$ dose-dependently displaced $\left[{ }^{3} \mathrm{H}\right]-\mathrm{fMLF}$ in FPR1-transfected rat basophilic leukemia (RBL) cells with $\mathrm{IC}_{50}$ values of $1.8 \mu \mathrm{M}$ and $100 \mathrm{nM}$, respectively [30], they did not exhibit any obvious inhibitory effects on FPR2-mediated cellular functions [29, 30]. Loor et al. [31] conducted comprehensive structure-activity relationship (SAR) analysis of sixty naturally occurring or biosynthetically produced cyclosporine analogs for their ability to inhibit $f$ MLFinduced responses in differentiated HL-60 cells. Some of these cyclosporines, including naturally occurring FR901459 and SDZ 214-103, inhibited $f$ MLF-induced $N$-acetyl- $\beta$-Dglucosaminidase release with nanomolar $\mathrm{IC}_{50}$ values [31]. Cyclosporine FR901459 was nearly 20-fold more potent than CsA but 4-fold less potent than $\mathrm{CsH}$ for inhibiting the FPR1-dependent response [32]. Extensive chemical modification of the cyclosporine scaffold led to the discovery of various non-immunosuppressive cyclophilin inhibitors for the treatment of hepatitis $\mathrm{C}$ infection and other diseases [33, 34]. However, the effects of these synthetic cyclosporine analogs on FPR functions have not been reported.

The mechanism responsible for the cyclosporines ability to act as FPR1 antagonists is still unclear, although it has been suggested that they may occupy an area of the receptor that covers or overlaps with the FPR1 ligand binding site or that they can produce an allosteric effect that causes reduced binding at this receptor [31]. It has also been suggested that cyclosporines 
may act as inverse agonists of FPR1 by recruiting different inactive FPR1 conformers [31, 35]. Zhou et al. [36] found that FPR1 amino acid 101 may be part of the binding site for CsA and CsH. Compared with the Val101 variant, variants of FPR1 with Leu101 displayed significantly improved receptor affinity, thereby enhancing cyclosporine antagonism of FPR1-mediated functions [36]. On the other hand, when we performed molecular docking of $\mathrm{CsH}$ into the structures of both Val101 and Leu101 variants, we found that the docking pose of CsH overlapped well with that of $f$ MLF for both FPR1 variants. Closer inspection, however, showed that CsH binds the Val101 FPR1 variant in quite a different pose compared to the Leu101 variant and is located closer to channel $\mathbf{C}$ of the protein surface (Figure 2; orthosteric FPR1 binding site regions are designated as in our previous publication [37]). Although CsH docking with either the Leu101 or Val101 FPR1 variant formed H-bonds with Arg205 and Tyr257, CsH also formed an H-bond with Cys98 of the Val101 variant, which is located in the vicinity of channel $\mathbf{C}$. Possibly, this $\mathrm{H}$-bond constrains $\mathrm{CsH}$ in a relatively unfavorable position that reduces its antagonist activity. Note that our molecular modeling assumed that peptides with up to 11 amino acids could fit into the orthosteric binding site, which is consistent with the size of CsH. This assumption is in contrast to older studies suggesting that the FPR1 binding pocket could accommodate no more than six amino acids [38]. Clearly, further studies are necessary to explore this issue. Although CsH has a good docking pose inside the FPR1 ligand binding site, allosteric effects could also occur via cyclosporine insertion deep into the FPR1 transmembraneextracellular domain interface.

In animal experiments, cyclosporine $\mathrm{H}$ blocked $f$ MLF-induced analgesia [39] and attenuated the acute inflammatory response evoked by cigarette smoke [40]. However, in vivo studies of cyclosporines should be interpreted carefully because their main therapeutic effects appear to involve signaling pathways unrelated to FPR1 [36]. Indeed, CsA, a relatively large 
molecule, inhibited the T-cell receptor signal transduction pathway via the formation of a CsAcyclophilin complex, which in turn bound to and inhibited the $\mathrm{Ca}^{2+}$-calmodulin dependent phosphatase calcineurin [41]. CsA also inhibited formation and opening of the mitochondrial permeability transition pore [42]. Although $\mathrm{CsH}$ does not bind to immunophilin, this peptide is a potent inhibitor of $\mathrm{Ca}^{2+}$-calmodulin-dependent phosphorylation of elongation factor 2 (EF-2) [43].

The urokinase receptor-derived peptide ${ }^{88}$ Ser-Arg-Ser-Arg-Tyr ${ }^{92}$ was previously reported as a mixed FPR1/FPR2 agonist [44]. Recently it was discovered that cyclized SRSRY had an opposite effect on cell migration, as compared to its linear form, and inhibited fMLF-induced monocyte locomotion with an $\mathrm{IC}_{50}$ value of $10 \mathrm{pM}$ [45]. The cyclic peptide inhibited binding of fluorescein isothiocyanate (FITC)-labeled $f$ MLF to FPR1 transfected cells [45], suggesting it might also be a receptor antagonist.

Yang et al. [46] found that an extract of bioactive secondary metabolites from a marine Bacillus sp. inhibited binding of a labeled formyl peptide to FPR1 in human neutrophils and FPR1-transfected HEK293 cells. However, the authors did not isolate the active metabolite(s). It should be noted that a large proportion of the secondary metabolites produced by the Bacillus isolates are cyclic lipopeptides belonging to three families, including iturins, fengycins, and surfactins [47]. Thus, these pure compounds may also represent novel FPR1 antagonists and should be evaluated.

\subsection{Natural non-cyclic peptide FPR1 antagonists and their synthetic analogs}

Chemotaxis inhibitory protein of Staphylococcus aureus (CHIPS), a 121-residue protein (14.1 kDa) excreted by several strains of $S$. aureus, has been reported to be an FPR1 and complement component 5a receptor (C5aR) antagonist [48]. Radiolabeled CHIPS bound FPR1 
with an apparent $\mathrm{K}_{\mathrm{d}} \sim 35 \mathrm{nM}$, indicating that the protein binds directly to FPR1 and blocks this receptor for ligation of $N$-formylated peptides [48]. Thus, inhibiting $f$ MLF-induced neutrophil chemotaxis may be a significant virulence factor for the invasion of $S$. aureus, and antibodies targeting CHIPS may be useful in the treatment of this infection [49]. Further studies on the region of CHIPS responsible for FPR1-blocking activity showed that peptide FTFEPF (the first 6 $N$-terminal amino acids) exhibited FPR1 antagonist activity, although the activity was 10,000fold less than CHIPS itself [50]. Additionally, this peptide was unable to inhibit the activation of neutrophils by C5a [50].

$N$-formylated peptides (such as $f$ MLF) are present in bacteria, which formylate their proteins during synthesis. Mitochondrial proteins also contain $\mathrm{N}$-formyl modifications, and these formylated proteins can be released from damaged mitochondria during tissue injury, leading to phagocyte recruitment (reviewed in [4]). Substitution of the formyl group with $t$-Boc, $i$-Boc, or a carbobenzoxy group transforms $f$ MLF to peptides with FPR1 antagonist properties [51], with the most potent being $t$-Boc-MLF (usually designated as Boc-1) (Table 1). Several less potent FPR1 antagonists have also been synthesized based on the $f$ MLF sequence [52]. Another potent FPR1/FPR2 pan-antagonist is synthetic peptide Boc-2; however, this peptide and other synthetic FPR1 antagonists $[53,54]$ have no closely related natural product homologues. Because Boc-1 is one of most potent and specific FPR1 antagonists described so far [29], Yuan et al. [55] created comparison docking poses of this peptide and fMLF using an homology FPR1 model that was based on structure of the chemokine receptor CXCR4 [55]. They found that the Phe residue of $f$ MLF was engaged in a stable H-bond network, formed by the side chains of Arg84, Lys85 and Asp284, while a water molecule mediated H-bonding between the fMLF carbonyl group and Asp284. Similarly, the Boc-1 also formed H-bonds directly with Arg84 and Lys85. However, in contrast to $\mathrm{fMLF}$, an H-bond of Boc-1 with Asp-284 was not created by a water molecule. 
Instead, the NH group of the peptide bond in the Phe residue of Boc-1 directly formed an H-bond with Asp284. This finding suggests an important role of the water molecule in discrimination between FPR1 agonists and antagonists.

Spinorphin (LVVYPWT), an endogenous anti-nociceptive non-cyclic peptide, was reported to be an FPR1 antagonist [56, 57]. However, this peptide also had direct FPR1 agonist activity [56], which may lead to desensensitization of this receptor rather than antagonism.

Saropeptate (aurantiamide acetate), a trypanocidal dipeptide composed of $\mathrm{N}$ benzoylphenylalanine and phenylalaninol acetate (Table 1) isolated from various plants and fungi (e.g., [58, 59]), inhibited $\mathrm{O}_{2}^{-\cdot}$ production by $f$ MLF-stimulated neutrophils [60]. Twentyfour new dipeptide analogs of saropeptate were synthesized and evaluated for effects on ROS production and HNE release by $f$ MLF-stimulated human neutrophils. Among them, seven $N$ (fluorenyl-9-methoxycarbonyl) (Fmoc)-dipeptides showed potent inhibitory effects [61]. Further SAR analysis based on synthesis of a series of Trp-containing dipeptides led to the discovery of several potent dipeptides that inhibited ROS production and HNE release by $f$ MLF-stimulated neutrophils $\sim 10-20$-fold better than by WKYMVm-stimulated neutrophils, with the most potent being dipeptides 3 (Table 1) and 24a [62]. Although the authors concluded these dipeptides were FPR1 antagonists, this conclusion requires further support by additional experiments, as direct activation and FPR1 binding were not assessed for these analogs. Indeed, the structures of these dipeptides resemble previously described Trp- and Phe-based derivatives that are potent FPR1/FPR2 agonists [63].

\subsection{Pepducins}

Mutagenesis studies [64] demonstrated that the third intracellular loop (i3) of GPCRs mediates a large part of the coupling between receptor and G protein, and synthesized lipidated 
peptides based on a GPCR i3 sequence are called "pepducins" to reflect their properties as GPCR-specific regulators of signal transduction [65]. The lipid moiety facilitates translocation across the plasma membrane, where pepducins can then allosterically modulate signaling of their cognate receptor. Many pepducins and related lipopeptides that can specifically modulate the activity of diverse GPCR, including FPR have been identified (for review [66]). However, pepducins are not always specific for their designated target receptor. For example, pepducin F1Pal ${ }_{16}$, which contains a peptide sequence identical to the FPR1 i3, was found to inhibit FPR2dependent functional responses, but had no effect on FPR1 signaling [67]. Another pepducin, F2Pal ${ }_{16}$, containing 16 amino acids present in the FPR2 i3 and conjugated with palmitic acid, actually had agonist effects in human monocytes and neutrophils via FPR2 [68, 69]. Thus, to date there are no pepducins that able to specifically target FPR1.

\section{Small-molecule non-peptide FPR1 antagonists and their synthetic derivatives}

\subsection{Flavonoids, isoflavones, and their synthetic derivatives}

Flavonoids are an important class of synthetic and natural compounds that exhibit a broad range of biological activities [70]. Their closely related derivatives are isoflavones. Many flavonoids and isoflavones have inhibitory effects on $f$ MLF-induced neutrophil responses. However, ROS scavenging activity of flavonoids and isoflavones may also contribute to the observed effects [71, 72], especially in tests of $f$ MLF-induced ROS production (see Figure 1). For example, luteolin and apigenin apparently inhibited $\mathrm{O}_{2}^{-}$production in $f$ MLF-stimulated neutrophils [73-75], but these flavonoids also inhibited neutrophil $\mathrm{O}_{2}^{-}$generation induced by phorbol-12-myristate-13-acetate (PMA) and tyrosyl phosphorylation of proteins in $f$ MLF-treated human neutrophils [76, 77], suggesting ROS scavenging activity rather than FPR1 antagonism. 
Several synthetic isoflavone derivatives have been identified as small-molecule competitive FPR1 antagonists $[19,78,79]$. Recently, we evaluated 100 related $4 H$-chromen-4ones, including synthetic and naturally occurring isoflavones, for their ability to antagonize FPR1-dependent signaling in neutrophils and FPR1-transfected HL-60 and RBL cells and identified novel and potent FPR1-specific antagonists [79]. Chemicals structures of several selected synthetic isoflavones (isoflavones 36, 68, and 73) are shown in Table 1. However, none of the naturally occurring isoflavones that we tested, including genistein, daidzein, afrormosin, formononetin, and 7-hydroxyisoflavone inhibited $f \mathrm{MLF}$-induced $\mathrm{Ca}^{2+}$ mobilization in human neutrophils. Although biochanin A (Table 1) inhibited $\mathrm{Ca}^{2+}$ flux in neutrophils and transfected FPR1-HL60 cells, this isoflavone did not inhibit binding of labeled ligand (WKYMVm-FITC) to FPR1-HL60 cells [79]. In addition, we found that biochanin A and its synthetic 2trifluoromethyl derivative had direct agonist activity in FPR1-HL60 cells and primary neutrophils. Thus, biochanin $\mathrm{A}$ and its synthetic derivative may activate $\mathrm{Ca}^{2+}$ flux via pathways that lead to cross-desensensitization of FPR1 and/or cross-talk with the receptor. Indeed, several other synthetic and natural flavonoids, including apigenin, wogonin, genistein, kazinol B, and ugonin $\mathrm{U}$, have been reported to stimulate a $\mathrm{Ca}^{2+}$ flux in various cell lines $[80,81]$ and neutrophils $[82,83]$.

We found that the isoflavone genistein did not antagonize $f$ MLF-induced $\mathrm{Ca}^{2+}$ mobilization in FPR1-HL60 cells and human neutrophils [79]. Thus, the previously reported inhibitory effect of genistein on $\mathrm{fMLF}$-stimulated degranulation, aggregation, and ROS production in human neutrophils [84-86] may be related to mechanisms downstream of $\mathrm{Ca}^{2+}$ mobilization, such as ROS scavenger activity [87] and/or modulation of tyrosine kinasedependent signaling events [84, 88]. Indeed, the broad modulatory activity of genistein on neutrophil activity suggests a non-receptor mode of action. For example, genistein inhibited 
neutrophil adhesion/adherence activated by tumor necrosis factor (TNF) [89] or agonists of protease-activated receptor 2 (PAR2) [90]. Moreover, pretreatment of neutrophils with genistein potentiated fMLF-induced cell transmigration [91]. Another isoflavone, afrormosin, inhibited $f$ MLF-stimulated neutrophil degranulation at very high concentrations $\left(\mathrm{IC}_{50} \sim 67 \mu \mathrm{M}\right)$ [92]. Similarly, although isopedicin, a flavanone derived from Fissistigma oldhamii, inhibited fMLFinduced neutrophil $\mathrm{O}_{2}^{-}$production and $\mathrm{HNE}$ release, this compound did not inhibit $f$ MLFinduced $\mathrm{Ca}^{2+}$ flux in these cells [93].

Recently, we reported that FPR1 antagonists with a $4 H$-chromen-4-one scaffold were specific for FPR1 and did not inhibit FPR2, FPR3, or CXCR1-dependent responses. This specificity was supported by competition binding at FPR1 with the most potent compounds, including isoflavones 36, 68, and 73 (Table 1). SAR analysis of these compounds revealed the importance of a small hydrophobic group at position 2 and the nature of the substituent at position 7 of the $4 \mathrm{H}$-chromen-4-one scaffold. These synthetic isoflavone derivatives were inactive as direct agonists of FPR1/FPR2 and mouse Fpr1 and did not activate $\mathrm{Ca}^{2+}$ flux in murine or human neutrophils. Molecular modeling showed a higher degree of similarity of the active isoflavones to the pharmacophore model of FPR1 antagonists, which was developed based on the structure of previously reported potent FPR1 antagonists with diverse chemical scaffolds [79]. Thus, we concluded that $4 H$-chromen-4-one may represent a unique natural productinspired chemical scaffold for the development of specific FPR1 antagonists that do not have undesirable off-target effects.

A natural chromone, cnidimol A (Table 1), which was isolated from Cnidium monnieri was found to inhibit $f$ MLF-induced $\mathrm{O}_{2}^{-}$production and HNE release [94]. Likewise, the isoprenylated flavonoid ugonin 3 (Table 1) isolated from Helminthostachys zeylanica and several related ugonins potently inhibited similar $f$ MLF-induced functional responses [95, 96]. 
However, a related ugonin (ugonin $\mathrm{U}$ ) was found to directly activate PLC and $\mathrm{Ca}^{2+}$ flux in human neutrophils [97], suggesting possible receptor desensitization rather than antagonism. Binding of these compounds to FPR 1 and effects on $\mathrm{Ca}^{2+}$ mobilization were not reported. It should be noted that some flavonoids and isoflavones can also interact with other cellular receptors and enzymes that cross-talk with FPR1 signaling (reviewed in [98-100]).

\subsection{Coumarins}

Coumarins represent an important type of naturally occurring and synthetic oxygencontaining heterocycle with a benzopyrone scaffold and a wide variety of biological activities. Some coumarins have been used in the clinic because of their anticoagulant and antineurodegenerative properties (reviewed in [101, 102]). Several coumarins, including isoheraclenin, imperatorin, osthenol, bergapten, xanthyletin, alloxanthoxyletin, and demethylauraptenol were found to be inhibitors of $\mathrm{O}_{2}^{-}$production and HNE release by fMLFstimulated human neutrophils [94, 103-106]. Chemical structures of selected coumarins are shown in Table 1. Shen et al. [103] found that among 20 tested compounds, coumarins imperatorin, isoheraclenin, and osthol were the most potent inhibitors of $f$ MLF-induced $\mathrm{O}_{2}{ }^{-}$ generation [103]. However, it was recently reported that imperatorin has complex effects on ion channels, including an inhibitory effect on voltage-gated $\mathrm{K}^{+}$channels and ATP-sensitive $\mathrm{K}^{+}$ channels [107] and an agonist effect on transient receptor potential vanilloid 1 (TRPV1) ion channel [108]. Furthermore, we found that imperatorin directly activated $\mathrm{Ca}^{2+}$ flux in human neutrophils and transfected FPR1 HL-60 cells and that bergapten did not inhibit $\mathrm{Ca}^{2+}$ mobilization in $f$ MLF-stimulated human neutrophils and FPR1 HL-60 cells (Table 2), thus excluding these compounds as possible FPR1 antagonists. It should be noted that osthol is a known plant-derived compound with anti-inflammatory activity and a broad spectrum of 
molecular targets $[109,110]$. Osthol had a weak inhibitory effect on $f$ MLF-induced HNE release [94]. Although a related coumarin, osthenol, had potent inhibitory activity on $f$ MLF-induced $\mathrm{O}_{2}{ }^{-}$ production and HNE release [94], this compound was previously found to inhibit 5a-reductase type I, 5-lipoxygenase, and cyclooxygenase [111, 112], suggesting FPR-independent effects on cellular responses. Indeed, other cyclooxygenase inhibitors, such as celecoxib and indomethacin, have been reported to interfere with $f$ MLF-induced functional responses, such as chemotaxis [113]. Similar to flavonoids, coumarins can also act as ROS scavengers [114] (see Figure 1), so additional studies are necessary to verify their possible direct effects on FPR1.

\subsection{Quinones and naphthalenones}

A large number of natural products contain quinone/naphthoquinone chromophores. These compounds have diverse biological properties and are able to modulate cellular signaling processes mainly via regulation of gene expression and receptor tyrosine kinases (reviewed in [115]). There are several publications on their effects in $f$ MLF-treated neutrophils. For example, berryammone A and naphthalenone derivatives, berryammone B (Table 1) and 4-Omethylberryammone C, isolated from the stem of Berrya ammonilla exhibited a relatively potent inhibition of $f$ MLF-induced $\mathrm{O}_{2}{ }^{-}$generation and HNE release by neutrophils [116]. Likewise, a related methyl naphthalene carboxylate, lawsonaphthoate A (Table 1), and had potent inhibitory activity [73]. Although embelin, abruquinone A, and acetylshikonin inhibited fMLF-induced functional responses in neutrophils, these natural quinones also suppressed ionophore A23187induced biosynthesis of eicosanoids in neutrophils [117-119], and embelin directly inhibited enzymatic activity of purified 5-lipoxygenase [119]. Finally, ehretiquinone isolated from the root of Ehretia longiflora potently inhibited $f$ MLF-induced $\mathrm{O}_{2}^{-\cdot}$ production, although effects on 
fMLF-induced HNE release and other functional activities were not evaluated [120]. Whether these compounds actually antagonize FPR1 is still unknown.

\subsection{Lignans}

Lignans are naturally occurring plant phenols that are derived biosynthetically from phenylpropanoids. Lignans are of clinical interest because of their numerous pharmacological properties, such as the antitumor, hepatoprotective, estrogenic, antihypertensive, antifungal, sedative, and antioxidant activities, as well as their ability to inhibit platelet activating factor (PAF) (reviewed in [121]). Several plant-derived lignans have been evaluated for their ability to inhibit $f$ MLF-induced functional responses in neutrophils. For example, $\left(7 S^{*}, 8 R^{*}, 7^{\prime} R^{*}, 8^{\prime} S^{*}\right)$ icariol $\mathrm{A}_{2}-9-O-\beta$-xylopyranoside and (+)-9'-O-(Z)-feruloyl-5,5'-dimethoxylariciresinol isolated from Hygroryza aristata and Zanthoxylum avicennae, respectively, inhibited both $\mathrm{O}_{2}^{-\cdot}$ production and HNE release by $f$ MLF-stimulated neutrophils $[122,123]$. Among the five lignans isolated from Zanthoxylum ailanthoides [(-)-syringaresinol, 5',5"-didemethoxypinoresinol, (+)episesamin, glaberide I, and (-)-dihydrocubebin], only (+)-episesamin (Table 1) inhibited both $\mathrm{O}_{2}^{-}$production and HNE release by $f$ MLF-stimulated neutrophils [104]. However, we found that in addition to inhibiting $f$ MLF-induced $\mathrm{Ca}^{2+}$ flux, (+)-episesamin also directly activated $\mathrm{Ca}^{2+}$ flux in human neutrophils and FPR1 HL-60 cells (Table 2), suggesting the inhibitory effects may be due to FPR1 desensitization. Several biphenyl-type neolignans isolated from Magnolia officinalis, including 5-allyl-5'-(1"-hydroxyallyloxy)biphenyl-2,2'-diol, 4-allyl-2-(2'methylbenzofuran-5'-yl)phenol, magnolol, magnaldehyde D, randaiol (Table 1), and randainal, inhibited $\mathrm{O}_{2}^{-}$production and HNE release by $f$ MLF-induced human neutrophils with varying levels of potency [124]. Magnolol also inhibited $f$ MLF-induced human neutrophil chemotaxis [125] and was a weak inhibitor of $f$ MLF-stimulated $\mathrm{O}_{2}^{-\cdot}$ generation in rat neutrophils [126]. 
However, magnolol and related lignans also directly activated $\mathrm{Ca}^{2+}$ flux, $\mathrm{O}_{2}^{-\cdot}$ production, and HNE release by neutrophils $[124,127]$. Thus, the inhibitory effects of magnolol on $f$ MLFinduced responses are also likely related to FPR1 desensitization or possible crossdesensitization, as magnolol can also bind to the $\mathrm{GABA}_{\mathrm{A}}$ receptor [128]. Although honokiol inhibited $f$ MLF-induced $\mathrm{O}_{2}^{--}$production, cathepsin $\mathrm{G}$ release, $\mathrm{Ca}^{2+}$ flux, and neutrophil migration [129-131], further analysis suggested that honokiol is not a competitive/allosteric FPR1 antagonist. Rather, it can specifically modulate fMLF-mediated neutrophil activation by inhibiting Lyn activation, which subsequently interferes with the activation of PLC $\gamma 2$, AKT, p38, protein kinase $\mathrm{C}$, and membrane localization of $\mathrm{p} 47^{\text {phox }}[129]$.

Nordihydroguaiaretic acid (NDGA) is a lignan from the creosote bush (Larrea tridentata) [132]. Although NDGA can effectively inhibit $f$ MLF-induced ROS production and degranulation in human neutrophils [133-135], this lignan is a potent inhibitor of 5-, 12-, and 15lipoxygenases [136]. Another lignan, di-O-methyltetrahydrofuroguaiacin B, had a bi-phasic effect on $f$ MLF-induced ROS production in human neutrophils [137]. Lignan MSF-2 (5hydroxy-2-(4-hydroxy-3-methoxyphenyl)-3,7-dimethoxy-4H-chromen-4-one) purified from the fruit of Melicope semecarpifolia inhibited $f$ MLF-induced $\mathrm{O}_{2}^{-\cdot}$ production, cathepsin G release, and cell chemotaxis, while the intracellular $\mathrm{Ca}^{2+}$ release was only partially reduced in human neutrophils [138]. Because MSF-2 did not interfere with $f$ MLF binding, the authors suggested that this lignan has targets downstream of FPR1, possibly PI3K.

Among the lignans reported to inhibit $f$ MLF-induced responses in neutrophils, only PP-6 [(2R, 3R)-2-(3',4'-dihydroxybenzyl)-3-(3",4"-dimethoxybenzyl)butyrolactone] (Table 1), which was isolated from Piper philippinum, blocked $f$ MLF binding to FPR1 $\left(\mathrm{IC}_{50} \sim 1.5 \mu \mathrm{M}\right)$ [139]. It also inhibited $f$ MLF-induced intracellular $\mathrm{Ca}^{2+}$ mobilization, $\mathrm{O}_{2}^{-}$production, and phosphorylation of ERK 1/2, Akt and p38 [139], suggesting direct antagonist activity. 
Furfuran type lignans, such as matairesinol, lariciresinol and pinoresinol, are widely distributed in edible plants, and most of these dietary lignans are converted by intestinal microbiota to the lignans enterolactone (Table 1) and enterodiol. These mammalian lignans have been suggested to have anti-carcinogenic activity [140]. Enterolactone is an isomer of PP-6 and can also inhibit ROS production by $f$ MLF-stimulated human neutrophils [133]. We evaluated enterolactone and found that it did not inhibit $\mathrm{Ca}^{2+}$ flux in $f$ MLF-stimulated human neutrophils and FPR1 HL-60 cells and also did not directly activate these cells (Table 2), indicating its target is likely not FPR1.

\subsection{Triterpenes, steroids, and saponins}

The triterpenes are one of the most numerous and diverse groups of natural plant products. These compounds have 4- or 5-ring skeletons and hydroxyl, carboxyl, or oxo groups and are biosynthesized in plants via squalene cyclization. Several triterpenoids isolated from the stems of Microtropis fokienensis inhibited fMLF-induced $\mathrm{O}_{2}{ }^{-}$generation and HNE release by neutrophils, with the most potent being 30-hydroxy-2,3-seco-lup-20(29)-ene-2,3-dioic acid (triterpene 17; Table 1), bearing two carboxylic groups [141]. Oleanolic (Table 1), ursolic, and betulinic acids are known triterpenes with anti-inflammatory and immunomodulatory properties [142]. Oleanolic acid has been reported to inhibit $f$ MLF-induced responses, including $\mathrm{O}_{2}^{-}$and HNE production by neutrophils [143-146]. The activity of this triterpene on $\mathrm{O}_{2}^{-}$production was $~$ 8-fold higher in neutrophils stimulated with $f$ MLF compared to those stimulated with PMA [145]. We found that oleanolic acid has a relatively high inhibitory activity on $\mathrm{Ca}^{2+}$ flux in fMLF-stimulated human neutrophils and FPR1 HL-60 cells without a direct agonist effect in these cells (Table 2), suggesting that this compound could be a true FPR1 antagonist. Epibetulinic acid (Table 1) isolated from Pachycentria formosana demonstrated similar 
inhibitory effects as oleanolic acid [143], and its derivative, betulinic acid, also inhibited fMLFinduced $\mathrm{O}_{2}{ }^{-}$production by neutrophils. However, this triterpene did not affect $f$ MLF-induced release of HNE [116], suggesting that it has an FPR1-independent mechanism of action. Although $\alpha$-amyrin, uvaol, ursolic acid, 19 $\alpha$-hydroxy ursolic acid, and 19 $\alpha$, 24-dihydroxy ursolic acid inhibited $f$ MLF-induced $\mathrm{O}_{2}^{-}$production, all of these triterpenes also inhibited $\mathrm{O}_{2}{ }^{-\cdot}$ generation stimulated by arachidonic acid [147], suggesting nonspecific effects of these compounds and/or interaction with post-FPR1 pathways.

Steroids are derivatives of triterpene in both plants and animals. Bile acids are steroid acids found predominantly in the bile of mammals and other vertebrates. These endogenous anionic detergents are produced by the liver and contain a rigid steroidal hydrophobic scaffold. Although bile acids were considered previously as catabolic products of cholesterol involved in the solubilization of various lipids and lipid-soluble compounds in the gut, they have recently been described as signaling molecules involved in many physiological functions. At least two these acids, deoxycholic acid (DCA) and chenodeoxycholic acid (CDCA) have been reported to antagonize FPR1 and inhibit ${ }^{3} \mathrm{H}-f \mathrm{MLF}$ binding at high concentrations $(\geq 100 \mu \mathrm{M})[148,149]$. Chen et al. [148] reported that CDCA inhibited $f$ MLF-induced $\mathrm{Ca}^{2+}$ flux in human monocytes with an $\mathrm{IC}_{50}$ of $40 \mu \mathrm{M}$ [148]. We found that DCA and CDCA were both weak inhibitors of $\mathrm{Ca}^{2+}$ mobilization in fMLF-stimulated human neutrophils and FPR1 HL-60 cells but that they also directly activated $\mathrm{Ca}^{2+}$ flux in these cells (Table 2). Thus, DCA and CDCA may activate $\mathrm{Ca}^{2+}$ flux via FPR1-dependent and/or independent pathways, leading to FPR1 desensensitization and/or cross-talk with the receptor.

Another bile acid, tauroursodeoxycholic acid also inhibited fMLF-induced $\mathrm{Ca}^{2+}$ mobilization at relatively high concentrations $\left(\mathrm{IC}_{50} \sim 0.5 \mathrm{mM}\right)$ [150]. Note, however, that the synthetic anionic detergent sodium dodecyl sulfate has also been reported to antagonize FPR1 
and reduce binding of labeled peptide to this receptor [151]. Thus, allosteric effects could also occur via interaction of the bile acids/detergents with FPR1 at the transmembrane-extracellular interface (see Figure 1), similar to the proposed mechanism for cyclosporines.

A pharmacophore model for bile acid recognition by FPR1 and docking poses of DCA and CDCA into the rhodopsin homology-based FPR1 structure were reported by Ferrari et al. [152]. This model is based on four anchor points, including two hydrophobic centers, one $\mathrm{H}-$ bonding donor site, and one H-bonding acceptor/negative site. In the docked pose, three stabilizing H-bond interactions are observed between DCA and Thr177, Tyr257, and Thr265. While the interaction with Tyr257 is crucial for anchoring of the DCA and CDCA carboxylic group to FPR1, H-bonding with Tyr177 and Thr265 determines the potency of the bile acids [152].

Bile acids have multiple physiological functions, including activation of the farnesoid $\mathrm{X}$ receptor (FXR), Takeda G-protein-coupled receptor (TGR5), and G protein-coupled bile acid receptor 1 (GPBAR1) [153, 154]. Both FXR and TGR5 demonstrate pleiotropic functions, including immune modulation. Recently it was found that bile acids can also activate ryanodine receptors [155], which are the major cellular mediator of calcium-induced calcium release. Although current studies shown a role of FPR in liver injury (e.g., [156]), involvement of bile acids as FPR1 ligands in liver pathology is still unknown. Indeed, endogenous bile acids can reduce liver neutrophil infiltration and prevent hepatotoxicity, which is similar to effects of the FPR1 antagonist Boc-1 [157].

Plant steroids have not been well studied for their effects on $f$ MLF-stimulated functional responses in leukocytes. High concentrations (30-100 $\mu \mathrm{M})$ of stigmast-4-ene-3,6-dione and hecogenin isolated from Polygonum chinensis inhibited $\mathrm{O}_{2}{ }^{-}$production by $f$ MLF-stimulated rat 
neutrophils, whereas stigmastane-3,6-dione was non-active [60]. Further work is necessary to assess the specificity and receptor targets of these plant steroids.

Triterpenoids and steroids containing one or more sugar moieties attached to the triterpenoid/steroid aglycones are called saponins. Several saponins have been evaluated for their ability to inhibit $f$ MLF-induced functional responses by neutrophils. For example, among the five saponins of oleanolic acid isolated from the rhizome of Anemone raddeana, OTS-3 inhibited $f$ MLF-induced $\mathrm{O}_{2}^{-}$production and did not suppress this response stimulated by PMA or arachidonic acid [158]. Five saponins, including taibaienoside I, chikusetsusaponin-Ib, and chikusetsusaponin-Iva, isolated from the roots of Panax japonicus var. major inhibited fMLFstimulated neutrophils [146]. Likewise, 3-O-[3-D-glucopyranosyl( $1 \rightarrow 2)-\beta$-D-glucopyranosyl]hederagenin from the buds of Aralia elata suppressed $\mathrm{O}_{2}{ }^{-\cdot}$ generation induced by $f$ MLF in a concentration-dependent manner [159], and both drangustoside A and B from Dracaena angustifolia Roxb inhibited HNE release by fMLF-stimulated neutrophils [160].

Although none of these triterpenes and their saponins have been evaluated for direct FPR1 binding activity, SMG-1 (hederagenin 3-O-(3,4-O-di-acetyl- $\alpha$-L-arabinopyranoside)$(1 \rightarrow 3)$ - $\alpha$-1-rhamnopyranosyl-( $1 \rightarrow 2)$ - $\alpha$-1-arabinopyranoside) blocked binding of fluorescent FPR1 ligand in human neutrophils and inhibited $f$ MLF-induced $\mathrm{O}_{2}{ }^{-}$production and HNE release by these cells [161]. Because the saponinogen of SMG-1 was not studied, we evaluated the effect of hederagenin and found that this compound inhibited $f$ MLF-induced $\mathrm{Ca}^{2+}$ flux in human neutrophils and FPR1 HL-60 cells. Importantly, hederagenin did not have direct agonist effects (Table 2), suggesting that it could potentially be an FPR1 antagonist. However, further studies are necessary to address this issue.

\subsection{Diterpenes and sesquiterpene lactones}


Sesquiterpene lactones and diterpenes are primary natural secondary metabolites. The trinorditerpene flueggrene A, which is isolated from the roots of Flueggea virosa, and the clerodane diterpenoid PL3S (Table 1) from Polyalthia longifolia var. pendulawere were both found to be potent inhibitors of $\mathrm{O}_{2}^{-}$production and $\mathrm{HNE}$ release by $f$ MLF-stimulated neutrophils $[162,163]$. Moreover, PL3S also inhibited $f$ MLF-induced $\mathrm{Ca}^{2+}$ mobilization in neutrophils [163]. The tetracyclic diterpenoid ent-kaurane 1 (16ß,17-dihydroxy-ent-kauran-19oic acid; Table 1) isolated from Annona squamosa inhibited $f$ MLF-induced $\mathrm{O}_{2}{ }^{-}$production, HNE release, and $\mathrm{Ca}^{2+}$ mobilization in human neutrophils without ROS scavenging or direct inhibition of HNE activity [164, 165]. Among several clerodane diterpenoids isolated from Polyalthia longifolia var. pendula, 16-oxocleroda-3,13(14)E-dien-15-oic acid methyl ester was found to be a potent inhibitor of $f$ MLF-induced $\mathrm{O}_{2}^{-}$production by neutrophils; however, the effects of this diterpene on other $f$ MLF-stimulated functional responses were not studied [166].

Various diterpenoids isolated from the soft corals Sarcophyton tortuosum, Cladiella krempfi, Cladiella krempfi, Cespitularia taeniata, and Junceella fragilis have also been evaluated for their ability to inhibit $f$ MLF-induced $\mathrm{O}_{2}^{-\cdot}$ production and HNE release. Most of the coralderived diterpenoids had low activity or were inactive [167-176]; however, the eunicellin-based diterpenoid klymollin M (Table 1) isolated from the soft coral Klyxum molle was a potent inhibitor of $f$ MLF-induced responses [177]. Again, the mechanisms involved have not been defined.

The effects of sesquiterpene lactones on FPR1-mediated functional responses have been less studied, and only few reports have been published. For example, Arakawa et al. [178] found that the furanoheliangolide budlein A isolated from Viguiera robusta inhibited release of HNE by $f$ MLF-stimulated neutrophils $\left(\mathrm{IC}_{50}=16.8 \mu \mathrm{M}\right)$, but the effect was not specific for FPR1, as this compound also inhibited degranulation of PAF-stimulated neutrophils. Six 
furanogermacrane sesquiterpenes isolated from Neolitsea parvigemma and the sesquiterpenoids hiiranlactone B and hiiranlactone D isolated from the leaves of Neolitsea hiiranensis exhibited mild/weak inhibitory activity against $f$ MLF-induced $\mathrm{O}_{2}^{-\cdot}$ production, although effects on other fMLF-induced neutrophil responses were not studied [179, 180]. Germacranolide isolated from Dimerostemma brasilianum had a similar profile of biological activity and suppressed HNE release by $f$ MLF- and PAF-stimulated neutrophils with $\mathrm{IC}_{50}$ values of $\sim 27.0$ and $23.0 \mu \mathrm{M}$, respectively [181].

A well-known sesquiterpene lactone studied in clinical trials, artemisinin (Table 1) [182], was previously not tested for its effects on FPR1-mediated responses. Thus, we evaluated its effects on $\mathrm{Ca}^{2+}$ flux in human neutrophils and FPR1 HL-60 cells and found that artemisinin was inactive in these assays (Table 2), suggesting its target is likely not FPR1.

\subsection{Miscellaneous compounds}

Natural plant-derived compounds with different chemical scaffolds than those reviewed above have also been reported to inhibit $f$ MLF-induced functional activities in human neutrophils or other FPR1 expressing cells. For example, benzophenone and phloroglucinol derivatives isolated from the fruits of Garcinia multiflora [183-185] and seeds of Garcinia subelliptica [186, 187] inhibited $f$ MLF-induced responses, with the most potent being garcimultiflorone B (Table 1). Several phthalides isolated from Pittosporum illicioides had weak inhibitory activity on fMLF-induced $\mathrm{O}_{2}^{--}$production and HNE release by neutrophils [188]. Alkaloids aristolatams IIIa

(Table 1) from Aristolochia manshuriensis and evofolin B, decarine, and ailanthamide from Zanthoxylum ailanthoides were also potent inhibitors of neutrophil $\mathrm{O}_{2}^{-}$production and $\mathrm{HNE}$ release [104, 106, 162, 189]. Similarly, phenanthrenedione pterolinus K (Table 1) isolated from Pterocarpus santalinus was a potent inhibitor of $f \mathrm{MLF}-$ induced $\mathrm{O}_{2}^{-\cdot}$ production and $\mathrm{HNE}$ release 
[190]. Although rutaecarpine, an alkaloid isolated from Evodia rutaecarpa, was a mild inhibitor of $f$ MLF-induced HNE release and ROS production [191], this alkaloid has a broad spectrum of biological activity, including inhibition of cyclooxygenase-2 [192] and activation of the TRPV1 ion channel [193, 194], suggesting that this molecule could interact with downstream processes in the FPR1 pathway.

Several compounds with mild inhibitory effects on $f$ MLF-induced responses in neutrophils, including 9-acetoxy-8,10-epoxythymol-3-O-tiglate, 10-acetoxy-8-hydroxy-9-Oangeloylthymol, and 1-[2-hydroxy-4-(hydroxymethyl)phenyl]ethan-1-one, have been isolated from Eupatorium cannabinum [195]. Lawsochylin A (Table 1) and (4S)-4-hydroxy- $\alpha$-tetralone isolated from Lawsonia inermis also inhibited fMLF-induced responses [73]. Recently, we found that 6-methyl-3,5-heptadien-2-one, which is a minor constituent in essential oils from Artemisia kotuchovii [196] and oleoresins from paprika and tomato [197], could non-specifically inhibit all functional responses that we tested in human neutrophils and FPR1-transfected HL-60 cells, including $f$ MLF-stimulated $\mathrm{Ca}^{2+}$ flux and chemotaxis, PMA-induced ROS production, and interleukin 8-induced $\mathrm{Ca}^{2+}$ flux. We concluded that this compound may interfere with intracellular signaling pathways common to both FPR1 and CXCR1/2 [196]. Viscolin and bractelactone, which are chalcones from Viscum coloratum and Fissistigma bracteolatum, respectively, also inhibited $f$ MLF-induced $\mathrm{O}_{2}{ }^{-}$production and HNE release by neutrophils; however, these compounds did not inhibit $f$ MLF-induced $\mathrm{Ca}^{2+}$ flux $[198,199]$, suggesting targets other than FPR1. Likewise, inhibition of $f$ MLF-stimulated rat neutrophil respiratory burst activity by broussochalcone A, a prenylated chalcone isolated from Broussonetia papyrifera, was found to be due to the suppression of PKC [200]. The oligomeric procyanidin F2 isolated from grape seeds inhibited $f$ MLF-induced $\mathrm{Ca}^{2+}$ flux, chemotaxis, and ERK phosphorylation in human glioblastoma U-87 cells [201]. However, further studies showed that this procyanidin could 
directly induce $\mathrm{Ca}^{2+}$ flux and chemotaxis in U-87 cells [202], suggesting this compound is not an FPR1 antagonist.

Compounds of various chemical classes were also isolated from marine sources and evaluated for their ability to inhibit $f$ MLF-induced functional responses in human neutrophils. Among of them, the tocopherol-derived metabolite hirsutocospiro A (Table 1) and methylfarnesylquinone isolated from the soft coral Cladiella hirsute and the brown alga Homoeostrichus formosana, respectively, inhibited $\mathrm{O}_{2}^{-}$production and HNE release [203, 204]. However, the specificity of these effects remains to be determined.

\section{Prediction of FPR1 antagonists among natural products using molecular modeling}

Natural-product-based drug discovery can be enhanced with computational methods [205]. Because most of the reported small-molecule natural inhibitors of $f$ MLF-induced functional responses were not evaluated in competition binding assays, we used molecular modeling to predict how well these compounds fit the FPR1 antagonist pharmacophore and their potential for binding to FPR1. The FPR1 antagonists described so far represent a wide range of chemotypes, and it is consequently difficult to derive meaningful SAR on structural grounds [206]. Recently, we built a pharmacophore model of FPR1 antagonists [79] based on field point methodology developed by Cheeseright et al. [207, 208]. This approach allowed us to compare diverse molecules in terms of their electrostatic field similarity and create an alignment of their bioactive conformations [206]. We found that three potent small-molecule synthetic non-peptide FPR1 antagonists that were identified previously using high-throughput screening and/or lead optimization [6-ethyl-2-methyl-3-(1-methyl-1H-benzimidazol-2-yl)-4-oxo-4H-chromen-7-yl acetate, $\quad N$-(1S)(1-(benzoimidazol-2-yl)-3-(methylthio)propyl)-5-ethoxy-3-methylbenzofuran-2carboxamide, and 6-benzyl-3-(2-chlorophenyl)-5-methyl-2-(trifluoromethyl)pyrazolo[1,5- 
a]pyrimidin-7(1H)-one (designated previously by us as compounds $\mathbf{1}, \mathbf{5}$, and $\mathbf{7}$ )] [78, 209] could be overlaid simultaneously with good correspondence of their molecular fields to form an FPR1 antagonist pharmacophore template [79]. Thus, we evaluated the ability of a given molecule to fit the FPR1 antagonist pharmacophore by construction of an extended 4-molecule template containing the molecule under investigation along with compounds $\mathbf{1}, \mathbf{5}$, and $\mathbf{7}$. The possibility of forming an extended template can be regulated by the magnitude of $\mu$ (maximum score variation between molecule pairs), which is an inner parameter of the FieldTemplater program, with lower values of $\mu$ indicating templates of higher similarity. We found that the previously reported FPR1 antagonists (isoflavones 36, 68, 73, and lignan PP-6) (see Table 1) gave extended templates with relatively low $\mu$ values $(0.03-0.04)$, indicating high similarity with the FPR1 antagonist pharmacophore, while inactive isoflavones (compounds 54, 58, and 70; compound numbers as designated previously [79]) generally had $\mu$ values $>0.04$ for obtaining an extended template. Based on the outcome of this small training set of 7 molecules, we utilized a simple rule of $\mu \leq 0.04$ for assessing potential as an FPR1 antagonist based on similarity with the antagonist pharmacophore and used this rule to evaluate a set of 24 naturally occurring compounds that were initially selected from our review of the literature and additional screening because they inhibited of all fMLF-induced functional responses tested but did not exhibit any direct agonist activity or other undesirable effects (Tables $\mathbf{2}$ and $\mathbf{3}$ ).

As result of this modeling study, most natural compounds under investigation did not fit into a satisfactory common 4-molecule FPR1 antagonist template (i.e., $\mu>0.04$ ). Although oleanolic acid and hederagenin showed promising results in our additional testing in human neutrophils and FPR1 HL-60 cells, these compounds were rejected as FPR1 antagonists by the modeling assessment of their ability to fit with the FPR1 antagonist pharmacophore. However, 
three compounds, in addition to PP-6 (i.e., garcimultiflorone B, cnidimol A, and PL3S), also had $\mu$ values $\leq 0.04$ and can be regarded as potential FPR1 antagonists based on all of the available biochemical and molecular modeling criteria. It should be noted that this modeling study is focused on orthosteric interaction of a ligand with FPR1, so allosteric antagonism cannot be excluded with some of the other compounds in the set.

To further investigate possible ligand binding, the natural compounds with ability to form a high-quality common 4-molecular template of FPR1 antagonists were subjected to molecular docking into the FPR1 ligand binding site. The best docking poses obtained for garcimultiflorone B, cnidimol A, PL3S, and PP-6 showed that these molecules were oriented similarly to $f$ MLF within the orthosteric FPR1 binding site of the Leu101 FPR1 variant (Figure 3A), again supporting their potential as FPR1 antagonists. All four natural compounds in their best docking

poses were located in area $\mathbf{D}$ and cavity $\mathbf{B}$, while garcimultiflorone B and MLF also occupied the entrance of channel A (notation of the FPR1 binging site regions according to [210]). Analysis of H-bond energies formed by the docked molecules (Table 4) indicated that PP-6 and cnidimol A formed much stronger H-bonds with FPR1 than PL3S and garcimultiflorone B. We found that H-bonds with Thr265 are formed for three of the four natural antagonists investigated by our docking methodology (Table 4). In addition, strong H-bonding interactions of cnidimol A and PP-6 were found with Asp106 and Arg205, respectively. As an example, all three Hbonds for PP-6 in the FPR1 ligand binding site are shown in Figure 3B.

\section{Discussion and concluding remarks}

FPR1 is considered to be a promising drug target for treating inflammatory and immunological diseases. Thus, natural compounds that could block and/or regulate FPR1 activity may be an important source of novel therapeutics for modulating inflammatory 
processes. Here, we reviewed the literature and conclude that only a few natural products and their synthetic derivatives are characterized well enough to be defined as FPR1 antagonists. CsH, CHIPS, cyclic peptide SRSRY, Boc-1, several synthetic isoflavones, PP-6, and SMG-1 are FPR1 antagonists with quantified FPR1 binding affinity. Conversely, numerous other natural compounds with the ability to suppress $\mathrm{O}_{2}^{-}$production and HNE release and/or other functional activities in $f M L F$-stimulated neutrophils that have been reported have not been evaluated for direct FPR1 binding activity and/or had off-target effects, suggesting that they could not be bona fide receptor antagonists.

In an effort to uncover additional natural products that may represent potential FPR1 antagonists, we used this review of the literature and additional screening of selected compounds for their ability to inhibit $\mathrm{Ca}^{2+}$ flux in $f \mathrm{MLF}$-stimulated human neutrophils to define a set of potential FPR1 antagonists. For a compound to be considered, it had to: $(a)$ inhibit all $f$ MLFinduced functional responses studied; $(b)$ not directly inhibit known processes downstream of FPR1 that could interfere with the functional responses tested, including inhibition of ion channels and eicosanoid biosynthesis; and (c) not directly activate functional responses in neutrophils. Based on all of these restrictions, we selected a prospective set of 24 natural products from the literature that were all relatively potent inhibitors of $f$ MLF-induced signaling $\left(\mathrm{IC}_{50}<30 \mu \mathrm{M}\right)$ and conducted molecular modeling to see if these compounds fit the structural requirements of an FPR1 antagonist. Four natural compounds (cnidimol A, PP-6, PL3S, and garcimultiflorone B) met this additional requirement, suggesting they may be FPR1 antagonists. Indeed, one of these compounds (PP-6) has already been shown to compete with $f$ MLF for binding to FPR1 [139]. Thus, further investigation of the binding of cnidimol A, PL3S, and garcimultiflorone B to the FPR1 ligand binding site will be important to evaluate. 
Cnidimol A has a $4 H$-chromen-4-one scaffold, which is similar to recently reported isoflavone FPR1 antagonists [79]. Thus, the high similarity of cnidimol A to the FPR1 pharmacophore model suggests $4 H$-chromen-4-one may represent an important scaffold for developing FPR1 antagonists. Although we predict garcimultiflorone B could be an FPR1 antagonist, it is also possible that this natural product could inhibit $f$ MLF-induced functional activity via downstream pathways, as some natural compounds related to garcimultiflorone B, such as garcinol and hyperforin, inhibited 5-lipoxygenase, a key enzyme in leukotriene biosynthesis $[211,212]$. Our docking study showed that PP-6 formed three H-bonds with FPR1. This lignan is structurally related to the mammalian lignans enterolactone and prestegane B. Various mammalian-type lignan derivatives are now commercially available and study of their FPR1-regulatory activity would be desirable. Importantly, key chemical moieties of these natural compounds could provide leads for the development of effective natural compoundinspired small molecule FPR1 antagonists.

Since our molecular modeling only evaluated orthosteric interaction of a ligand with FPR1, possible allosteric mechanisms for various compounds cannot be excluded. It is now recognized that GPCRs possess spatially distinct allosteric sites, and G protein-GPCR interactions, including $\beta$-arrestin-GPCR interactions, can involve allosteric interactions [213]. Thus, compounds that are able to interfere with these FPR1 interactions or directly insert into the FPR1 transmembrane-extracellular interface could modify FPR1-dependent signal transduction pathways. Finally, FPR1 molecules can interact laterally in the plasma membrane [214] and, for example, bile acids, plant steroids, and saponins may alter lateral allosteric regulation, modifying the membrane environment responsible for the receptor dimerization, FPR1 coupling with its G proteins, and other scaffolding/accessory proteins. 


\section{Acknowledgments}

This research was supported in part by National Institutes of Health IDeA Program COBRE grant GM110732; a USDA National Institute of Food and Agriculture Hatch project; and the Montana State University Agricultural Experiment Station. 


\section{References}

[1] Schiffmann E, Corcoran BA, Wahl SM. N-formylmethionyl peptides as chemoattractants for leucocytes. Proc Natl Acad Sci USA. 1975;72:1059-62.

[2] Williams LT, Snyderman R, Pike MC, Lefkowitz RJ. Specific receptor sites for chemotactic peptides on human polymorphonuclear leukocytes. Proc Natl Acad Sci U S A. 1977;74:1204-8.

[3] Boulay F, Tardif M, Brouchon L, Vignais P. Synthesis and use of a novel N-formyl peptide derivative to isolate a human N-formyl peptide receptor cDNA. Biochem Biophys Res Commun. 1990;168:1103-9.

[4] Ye RD, Boulay F, Wang JM, Dahlgren C, Gerard C, Parmentier M, et al. International Union of Basic and Clinical Pharmacology. LXXIII. Nomenclature for the Formyl Peptide Receptor (FPR) Family. Pharmacol Rev. 2009;61:119-61.

[5] Liu M, Zhao J, Chen K, Bian X, Wang C, Shi Y, et al. G protein-coupled receptor FPR1 as a pharmacologic target in inflammation and human glioblastoma. Int Immunopharmacol. 2012;14:283-8.

[6] Iribarren P, Zhou Y, Hu J, Le Y, Wang JM. Role of formyl peptide receptor-like 1 (FPRL1/FPR2) in mononuclear phagocyte responses in Alzheimer disease. Immunol Res. 2005;31:165-76.

[7] Cattaneo F, Parisi M, Ammendola R. Distinct signaling cascades elicited by different formyl Peptide receptor 2 (FPR2) agonists. Int J Mol Sci. 2013;14:7193-230.

[8] Kwon YW, Heo SC, Jang IH, Jeong GO, Yoon JW, Mun JH, et al. Stimulation of cutaneous wound healing by an FPR2-specific peptide agonist WKYMVm. Wound Repair Regen. 2015. In press.

[9] Kao W, Gu R, Jia Y, Wei X, Fan H, Harris J, et al. A formyl peptide receptor agonist suppresses inflammation and bone damage in arthritis. Br J Pharmacol. 2014;171:4087-96.

[10] Sun J, Dahlen B, Agerberth B, Haeggstrom JZ. The antimicrobial peptide LL-37 induces synthesis and release of cysteinyl leukotrienes from human eosinophils--implications for asthma. Allergy. 2013;68:304-11.

[11] Rabiet MJ, Huet E, Boulay F. The N-formyl peptide receptors and the anaphylatoxin C5a receptors: An overview. Biochimie. 2007;89:1089-106.

[12] Dufton N, Perretti M. Therapeutic anti-inflammatory potential of formyl-peptide receptor agonists. Pharmacol Ther. 2010;127:175-88.

[13] Dorward DA, Lucas CD, Chapman GB, Haslett C, Dhaliwal K, Rossi AG. The Role of Formylated Peptides and Formyl Peptide Receptor 1 in Governing Neutrophil Function during Acute Inflammation. Am J Pathol. 2015;185:1172-84.

[14] Corminboeuf O, Leroy X. FPR2/ALXR agonists and the resolution of inflammation. J Med Chem. 2015;58:537-59.

[15] Bloes DA, Kretschmer D, Peschel A. Enemy attraction: bacterial agonists for leukocyte chemotaxis receptors. Nat Rev Microbiol. 2015;13:95-104.

[16] Schepetkin IA, Khlebnikov AI, Giovannoni MP, Kirpotina LN, Cilibrizzi A, Quinn MT. Development of Small Molecule Non-peptide Formyl Peptide Receptor (FPR) Ligands and Molecular Modeling of Their Recognition. Curr Med Chem. 2014;21:1478-504.

[17] Butler MS. Natural products to drugs: natural product-derived compounds in clinical trials. Nat Prod Rep. 2008;25:475-516.

[18] Lachance H, Wetzel S, Kumar K, Waldmann H. Charting, navigating, and populating natural product chemical space for drug discovery. J Med Chem. 2012;55:5989-6001. 
[19] Edwards BS, Bologa C, Young SM, Balakin KV, Prossnitz ER, Savchuck NP, et al. Integration of virtual screening with high-throughput flow cytometry to identify novel small molecule formylpeptide receptor antagonists. Mol Pharmacol. 2005;68:1301-10.

[20] Selvatici R, Falzarano S, Mollica A, Spisani S. Signal transduction pathways triggered by selective formylpeptide analogues in human neutrophils. Eur J Pharmacol. 2006;534:1-11.

[21] Prossnitz ER, Ye RD. The N-formyl peptide receptor: a model for the study of chemoattractant receptor structure and function. Pharmacol Ther. 1997;74:73-102.

[22] Ptasznik A, Traynor-Kaplan A, Bokoch GM. G protein-coupled chemoattractant receptors regulate lyn tyrosine kinase Shc adapter protein signaling complexes. J Biol Chem. 1995;270:19969-73.

[23] Dinauer MC. Regulation of neutrophil function by Rac GTPases. Curr Opin Hematol. 2003;10:8-15.

[24] Yoshie O. Chemokine receptors as therapeutic targets. Nihon Rinsho Meneki Gakkai Kaishi. 2013;36:189-96.

[25] Quinn MT, Ammons MC, Deleo FR. The expanding role of NADPH oxidases in health and disease: no longer just agents of death and destruction. Clin Sci (Lond). 2006;111:1-20.

[26] Hoenderdos K, Condliffe A. The neutrophil in chronic obstructive pulmonary disease. Am J Respir Cell Mol Biol. 2013;48:531-9.

[27] Schofield ZV, Woodruff TM, Halai R, Wu MC, Cooper MA. Neutrophils--a key component of ischemia-reperfusion injury. Shock. 2013;40:463-70.

[28] Wenzel-Seifert K, Seifert R. Cyclosporin H is a potent and selective formyl peptide receptor antagonist. Comparison with N-t-butoxycarbonyl-L-phenylalanyl-L-leucyl-L-phenylalanyl-Lleucyl-L-phenylalanine and cyclosporins A, B, C, D, and E. J Immunol. 1993;150:4591-9.

[29] Stenfeldt AL, Karlsson J, Wennerås C, Bylund J, Fu H, Dahlgren C. Cyclosporin H, BocMLF and Boc-FLFLF are antagonists that preferentially inhibit activity triggered through the formyl peptide receptor. Inflammation. 2007;30:224-9.

[30] Yan P, Nanamori M, Sun M, Zhou C, Cheng N, Li N, et al. The immunosuppressant cyclosporin A antagonizes human formyl peptide receptor through inhibition of cognate ligand binding. J Immunol. 2006;177:7050-8.

[31] Loor F, Tiberghien F, Wenandy T, Didier A, Traber R. Cyclosporins: structure-activity relationships for the inhibition of the human FPR1 formylpeptide receptor. J Med Chem. 2002;45:4613-28.

[32] Tiberghien F, Wenandy T, Loor F. The potent immunosuppressive cyclosporin FR901459 inhibits the human P-glycoprotein and formyl peptide receptor functions. J Antibiot (Tokyo). 2000;53:509-15.

[33] Hopkins S, Gallay P. Cyclophilin inhibitors: an emerging class of therapeutics for the treatment of chronic hepatitis C infection. Viruses. 2012;4:2558-77.

[34] Fu J, Tjandra M, Becker C, Bednarczyk D, Capparelli M, Elling R, et al. Potent nonimmunosuppressive cyclophilin inhibitors with improved pharmaceutical properties and decreased transporter inhibition. J Med Chem. 2014;57:8503-16.

[35] Wenzel-Seifert K, Hurt CM, Seifert R. High constitutive activity of the human formyl peptide receptor. J Biol Chem. 1998;273:24181-9.

[36] Zhou C, Zhou Y, Wang J, Feng Y, Wang H, Xue J, et al. V101L of human formyl peptide receptor 1 (FPR1) increases receptor affinity and augments the antagonism mediated by cyclosporins. Biochem J. 2013;451:245-55. 
[37] Khlebnikov AI, Schepetkin IA, Quinn MT. Computational structure-activity relationship analysis of small-molecule agonists for human formyl peptide receptors. Eur J Med Chem. 2010;45:5406-19.

[38] Sklar LA, Fay SP, Seligmann BE, Freer RJ, Muthukumaraswamy N, Mueller H. Fluorescence analysis of the size of a binding pocket of a peptide receptor at natural abundance. Biochemistry. 1990;29:313-6.

[39] Rittner HL, Hackel D, Voigt P, Mousa S, Stolz A, Labuz D, et al. Mycobacteria attenuate nociceptive responses by formyl peptide receptor triggered opioid peptide release from neutrophils. PLoS Pathog. 2009;5:e1000362.

[40] Cardini S, Dalli J, Fineschi S, Perretti M, Lungarella G, Lucattelli M. Genetic ablation of the fprl gene confers protection from smoking-induced lung emphysema in mice. Am J Respir Cell Mol Biol. 2012;47:332-9.

[41] Fruman DA, Klee CB, Bierer BE, Burakoff SJ. Calcineurin phosphatase activity in T lymphocytes is inhibited by FK 506 and cyclosporin A. Proc Natl Acad Sci USA. 1992;89:368690.

[42] Broekemeier KM, Pfeiffer DR. Inhibition of the mitochondrial permeability transition by cyclosporin A during long time frame experiments: relationship between pore opening and the activity of mitochondrial phospholipases. Biochemistry. 1995;34:16440-9.

[43] Gschwendt M, Kittstein W, Marks F. The weak immunosuppressant cyclosporine D as well as the immunologically inactive cyclosporine $\mathrm{H}$ are potent inhibitors in vivo of phorbol ester TPA-induced biological effects in mouse skin and of $\mathrm{Ca}^{2+} /$ calmodulin dependent EF-2 phosphorylation in vitro. Biochem Biophys Res Commun. 1988;150:545-51.

[44] Gargiulo L, Longanesi-Cattani I, Bifulco K, Franco P, Raiola R, Campiglia P, et al. Crosstalk between fMLP and vitronectin receptors triggered by urokinase receptor-derived SRSRY peptide. J Biol Chem. 2005;280:25225-32.

[45] Yousif AM, Minopoli M, Bifulco K, Ingangi V, Di Carluccio G, Merlino F, et al. Cyclization of the urokinase receptor-derived ser-arg-ser-arg-tyr Peptide generates a potent inhibitor of trans-endothelial migration of monocytes. PLoS One. 2015;10:e0126172.

[46] Yang SC, Lin CF, Chang WY, Kuo J, Huang YT, Chung PJ, et al. Bioactive secondary metabolites of a marine Bacillus sp. inhibit superoxide generation and elastase release in human neutrophils by blocking formyl peptide receptor 1. Molecules. 2013;18:6455-68.

[47] Mondol MA, Shin HJ, Islam MT. Diversity of secondary metabolites from marine Bacillus species: chemistry and biological activity. Mar Drugs. 2013;11:2846-72.

[48] Postma B, Poppelier MJ, van Galen JC, Prossnitz ER, Van Strijp JA, de Haas CJ, et al. Chemotaxis inhibitory protein of Staphylococcus aureus binds specifically to the C5a and formylated peptide receptor. J Immunol. 2004;172:6994-7001.

[49] Wright AJ, Higginbottom A, Philippe D, Upadhyay A, Bagby S, Read RC, et al. Characterisation of receptor binding by the chemotaxis inhibitory protein of Staphylococcus aureus and the effects of the host immune response. Mol Immunol. 2007;44:2507-17.

[50] Haas PJ, de Haas CJ, Kleibeuker W, Poppelier MJ, van Kessel KP, Kruijtzer JA, et al. Nterminal residues of the chemotaxis inhibitory protein of Staphylococcus aureus are essential for blocking formylated peptide receptor but not C5a receptor. J Immunol. 2004;173:5704-11.

[51] Derian CK, Solomon HF, Higgins JD, 3rd, Beblavy MJ, Santulli RJ, Bridger GJ, et al. Selective inhibition of $\mathrm{N}$-formylpeptide-induced neutrophil activation by carbamate-modified peptide analogues. Biochemistry. 1996;35:1265-9. 
[52] Babich JW, Tompkins RG, Graham W, Barrow SA, Fischman AJ. Localization of radiolabeled chemotactic peptide at focal sites of Escherichia coli infection in rabbits: evidence for a receptor-specific mechanism. J Nucl Med. 1997;38:1316-22.

[53] Dalpiaz A, Ferretti ME, Vertuani G, Traniello S, Scatturin A, Spisani S. C- and N-terminal residue effect on peptide derivatives' antagonism toward the formyl-peptide receptor. Eur J Pharmacol. 2002;436:187-96.

[54] Hayashi R, Kitajima T, Mizuguchi H, Fujimoto M, Yamaguchi A, Koga S, et al. Development of potent antagonists for formyl peptide receptor 1 based on Boc-Phe-D-Leu-PheD-Leu-Phe-OH. Bioorg Med Chem. 2014;22:3824-8.

[55] Yuan S, Ghoshdastider U, Trzaskowski B, Latek D, Debinski A, Pulawski W, et al. The role of water in activation mechanism of human $\mathrm{N}$-formyl peptide receptor 1 (FPR1) based on molecular dynamics simulations. PLoS One. 2012;7:e47114.

[56] Liang TS, Gao JL, Fatemi O, Lavigne M, Leto TL, Murphy PM. The endogenous opioid spinorphin blocks fMet-Leu-Phe-induced neutrophil chemotaxis by acting as a specific antagonist at the N-formylpeptide receptor subtype FPR. J Immunol. 2001;167:6609-14.

[57] Yamamoto Y, Kanazawa T, Shimamura M, Ueki M, Hazato T. Inhibitory effects of spinorphin, a novel endogenous regulator, on chemotaxis, O2- generation, and exocytosis by $\mathrm{N}$ formylmethionyl-leucyl-phenylalanine (FMLP)-stimulated neutrophils. Biochem Pharmacol. 1997;54:695-701.

[58] Nwodo NJ, Okoye FB, Lai D, Debbab A, Brun R, Proksch P. Two trypanocidal dipeptides from the roots of Zapoteca portoricensis (Fabaceae). Molecules. 2014;19:5470-7.

[59] Yoon CS, Kim DC, Lee DS, Kim KS, Ko W, Sohn JH, et al. Anti-neuroinflammatory effect of aurantiamide acetate from the marine fungus Aspergillus sp. SF-5921: inhibition of NFkappaB and MAPK pathways in lipopolysaccharide-induced mouse BV2 microglial cells. Int Immunopharmacol. 2014;23:568-74.

[60] Tsai PL, Wang JP, Chang CW, Kuo SC, Chao PD. Constituents and bioactive principles of Polygonum chinensis. Phytochemistry. 1998;49:1663-6.

[61] Yen CT, Hwang TL, Wu YC, Hsieh PW. Design and synthesis of new N-(fluorenyl-9methoxycarbonyl) (Fmoc)-dipeptides as anti-inflammatory agents. Eur $\mathrm{J}$ Med Chem. 2009;44:1933-40.

[62] Hwang TL, Hung CH, Hsu CY, Huang YT, Tsai YC, Hsieh PW. Design and synthesis of tryptophan containing dipeptide derivatives as formyl peptide receptor 1 antagonist. Org Biomolec Chem. 2013; 11:3742-55.

[63] Schepetkin IA, Kirpotina LN, Khlebnikov AI, Jutila MA, Quinn MT. Gastrin-releasing peptide/neuromedin B receptor antagonists PD176252, PD168368, and related analogs are potent agonists of human formyl-peptide receptors. Mol Pharmacol. 2011;79:77-90.

[64] Kostenis E, Conklin BR, Wess J. Molecular basis of receptor/G protein coupling selectivity studied by coexpression of wild type and mutant $\mathrm{m} 2$ muscarinic receptors with mutant $\mathrm{G}$ alpha(q) subunits. Biochemistry. 1997;36:1487-95.

[65] Covic L, Gresser AL, Talavera J, Swift S, Kuliopulos A. Activation and inhibition of G protein-coupled receptors by cell-penetrating membrane-tethered peptides. Proc Natl Acad Sci USA. 2002;99:643-8.

[66] O'Callaghan K, Kuliopulos A, Covic L. Turning receptors on and off with intracellular pepducins: new insights into G-protein-coupled receptor drug development. J Biol Chem. 2012;287:12787-96. 
[67] Winther M, Gabl M, Welin A, Dahlgren C, Forsman H. A neutrophil inhibitory pepducin derived from FPR1 expected to target FPR1 signaling hijacks the closely related FPR2 instead. FEBS Lett. 2015;589:1832-9.

[68] Lee HY, Kim SD, Shim JW, Kim HJ, Kwon JY, Kim JM, et al. Activation of human monocytes by a formyl peptide receptor 2-derived pepducin. FEBS Lett. 2010;584:4102-8.

[69] Forsman H, Bylund J, Oprea TI, Karlsson A, Boulay F, Rabiet MJ, et al. The leukocyte chemotactic receptor FPR2, but not the closely related FPR1, is sensitive to cell-penetrating pepducins with amino acid sequences descending from the third intracellular receptor loop. Biochim Biophys Acta. 2013;1833:1914-23.

[70] Peluso I, Miglio C, Morabito G, Ioannone F, Serafini M. Flavonoids and immune function in human: a systematic review. Crit Rev Food Sci Nutr. 2015;55:383-95.

[71] Khlebnikov AI, Schepetkin IA, Domina NG, Kirpotina LN, Quinn MT. Improved quantitative structure-activity relationship models to predict antioxidant activity of flavonoids in chemical, enzymatic, and cellular systems. Bioorg Med Chem. 2007;15:1749-70.

[72] Lengyel J, Rimarcik J, Vaganek A, Klein E. On the radical scavenging activity of isoflavones: thermodynamics of $\mathrm{O}-\mathrm{H}$ bond cleavage. Phys Chem Chem Phys. 2013;15:10895903.

[73] Liou JR, El-Shazly M, Du YC, Tseng CN, Hwang TL, Chuang YL, et al. 1,5-Diphenylpent3-en-1-ynes and methyl naphthalene carboxylates from Lawsonia inermis and their antiinflammatory activity. Phytochemistry. 2013;88:67-73.

[74] Limasset B, Le Doucen C, Dore J-C, Ojasoo T, Damon M, De Paulet AC. Effects of flavonoids on the release of reactive oxygen species by stimulated human neutrophils. Multivariate analysis of structure-activity relationships (SAR). Biochem Pharmacol. 1993;46:1257-71.

[75] Tordera M, Ferrandiz ML, Alcaraz MJ. Influence of anti-inflammatory flavonoids on degranulation and arachidonic acid release in rat neutrophils. Z Naturforsch C. 1994;49:235-40.

[76] Lu HW, Sugahara K, Sagara Y, Masuoka N, Asaka Y, Manabe M, et al. Effect of three flavonoids, 5,7,3',4'-tetrahydroxy-3-methoxy flavone, luteolin, and quercetin, on the stimulusinduced superoxide generation and tyrosyl phosphorylation of proteins in human neutrophil. Arch Biochem Biophys. 2001;393:73-7.

[77] Ko HH, Weng JR, Tsao LT, Yen MH, Wang JP, Lin CN. Anti-inflammatory flavonoids and pterocarpanoid from Crotalaria pallida and C. assamica. Bioorg Med Chem Lett. 2004;14:10114.

[78] Young SM, Bologa CM, Fara D, Bryant BK, Strouse JJ, Arterburn JB, et al. Duplex highthroughput flow cytometry screen identifies two novel formylpeptide receptor family probes. Cytometry Part A. 2009;75:253-63.

[79] Schepetkin IA, Kirpotina LN, Khlebnikov AI, Cheng N, Ye RD, Quinn MT. Antagonism of human formyl peptide receptor 1 (FPR1) by chromones and related isoflavones. Biochem Pharmacol. 2014;92:627-41.

[80] Lin Y-L, Dai Z-K, Lin R-J, Chu K-S, Chen I-J, Wu J-R, et al. Baicalin, a flavonoid from Scutellaria baicalensis Georgi, activates large-conductance $\mathrm{Ca} 2+$-activated $\mathrm{K}+$ channels via cyclic nucleotide-dependent protein kinases in mesenteric artery. Phytomedicine. 2010;17:76070.

[81] Das A, Banik NL, Ray SK. Flavonoids activated caspases for apoptosis in human glioblastoma T98G and U87MG cells but not in human normal astrocytes. Cancer. 2010;116:164-76. 
[82] Wang J-P, Hsu M-F, Ko H-H, Lin C-N. Stimulation of cellular free Ca2+ elevation and inhibition of store-operated $\mathrm{Ca}^{2+}$ entry by kazinol B in neutrophils. Naunyn-Schmiedeberg's Arch Pharmacol. 2004;370:500-9.

[83] Chen CY, Liaw CC, Chen YH, Chang WY, Chung PJ, Hwang TL. A novel immunomodulatory effect of ugonin $\mathrm{U}$ in human neutrophils via stimulation of phospholipase $\mathrm{C}$. Free Radic Biol Med. 2014;72:222-31.

[84] Torres M, Hall FL, O'Neill K. Stimulation of human neutrophils with formyl-methionylleucyl-phenylalanine induces tyrosine phosphorylation and activation of two distinct mitogenactivated protein-kinases. J Immunol. 1993;150:1563-77.

[85] Wang C, Lu H, Chen G, Yamashita K, Manabe M, Kodama H. Effect of S-(1,2dicarboxyethyl) glutathione and S-(1,2-dicarboxyethyl) cysteine on the stimulus-induced superoxide generation and tyrosyl phosphorylation of proteins in human neutrophils. Clin Chem Lab Med. 2002;40:1101-4.

[86] Rotondo S, Krauze-Brzosko K, Manarini S, Martelli N, Pecce R, Evangelista V, et al. Inhibition by soya isoflavones of human polymorphonuclear leukocyte function: possible relevance for the beneficial effects of soya intake. Brit J Nutr. 2008;99:240-7.

[87] Kruk I, Aboul-Enein HY, Michalska T, Lichszteld K, Kladna A. Scavenging of reactive oxygen species by the plant phenols genistein and oleuropein. Luminescence. 2005;20:81-9.

[88] Grinstein S, Furuya W. Chemoattractant-induced tyrosine phosphorylation and activation of microtubule-associated protein kinase in human neutrophils. J Biol Chem. 1992;267:18122-5.

[89] Nitto T, Araki Y, Takeda Y, Sendo F. Pharmacological analysis for mechanisms of GPI-80 release from tumour necrosis factor-alpha-stimulated human neutrophils. $\mathrm{Br} \mathrm{J}$ Pharmacol. 2002;137:353-60.

[90] Yagi Y, Otani H, Ando S, Oshiro A, Kawai K, Nishikawa H, et al. Involvement of Rho signaling in PAR2-mediated regulation of neutrophil adhesion to lung epithelial cells. Eur $\mathrm{J}$ Pharmacol. 2006;536:19-27.

[91] Zen K, Reaves TA, Soto I, Liu Y. Response to genistein: assaying the activation status and chemotaxis efficacy of isolated neutrophils. J Immunol Meth. 2006;309:86-98.

[92] de Araujo Lopes A, Magalhaes TR, de Andrade Uchoa DE, Silveira ER, Azzolini AE, Kabeya LM, et al. Afrormosin, an Isoflavonoid from Amburana cearensis A. C. Smith, Modulates the Inflammatory Response of Stimulated Human Neutrophils. Basic Clin Pharmacol Toxicol. 2013;113:363-9.

[93] Hwang TL, Li GL, Lan YH, Chia YC, Hsieh PW, Wu YH, et al. Potent inhibition of superoxide anion production in activated human neutrophils by isopedicin, a bioactive component of the Chinese medicinal herb Fissistigma oldhamii. Free Radic Biol Med. 2009;46:520-8.

[94] Lee TH, Chen YC, Hwang TL, Shu CW, Sung PJ, Lim YP, et al. New coumarins and antiinflammatory constituents from the fruits of Cnidium monnieri. Int J Mol Sci. 2014;15:9566-78.

[95] Huang YC, Hwang TL, Yang YL, Wu SH, Hsu MH, Wang JP, et al. Acetogenin and prenylated flavonoids from Helminthostachys zeylanica with inhibitory activity on superoxide generation and elastase release by neutrophils. Planta Med. 2010;76:447-53.

[96] Huang YC, Hwang TL, Chang CS, Yang YL, Shen CN, Liao WY, et al. Anti-inflammatory flavonoids from the rhizomes of Helminthostachys zeylanica. J Nat Prod. 2009;72:1273-8.

[97] Chen CY, Liaw CC, Chen YH, Chang WY, Chung PJ, Hwang TL. A novel immunomodulatory effect of ugonin $\mathrm{U}$ in human neutrophils via stimulation of phospholipase $\mathrm{C}$. Free Radic Biol Med. 2014. 
[98] Reiter E, Reiter E, Beck V, Medjakovic S, Jungbauer A. Isoflavones are safe compounds for therapeutical applications - evaluation of in vitro data. Gynecol Endocrinol. 2009;25:554-80.

[99] Wahajuddin, Taneja I, Arora S, Raju KS, Siddiqui N. Disposition of pharmacologically active dietary isoflavones in biological systems. Curr Drug Metab. 2013;14:369-80.

[100] Douglas CC, Johnson SA, Arjmandi BH. Soy and its isoflavones: the truth behind the science in breast cancer. Anticancer Agents Med Chem. 2013;13:1178-87.

[101] Peng XM, Damu GL, Zhou C. Current developments of coumarin compounds in medicinal chemistry. Curr Pharm Des. 2013;19:3884-930.

[102] Katsori AM, Hadjipavlou-Litina D. Coumarin derivatives: an updated patent review (20122014). Expert Opin Ther Pat. 2014;24:1323-47.

[103] Shen DY, Chao CH, Chan HH, Huang GJ, Hwang TL, Lai CY, et al. Bioactive constituents of Clausena lansium and a method for discrimination of aldose enantiomers. Phytochemistry. 2012;82:110-7.

[104] Chung CY, Hwang TL, Kuo LM, Kuo WL, Cheng MJ, Wu YH, et al. New benzo[c]phenanthridine and benzenoid derivatives, and other constituents from Zanthoxylum ailanthoides: Effects on neutrophil pro-inflammatory responses. Int J Mol Sci. 2013;14:22395408.

[105] Chen JJ, Yang CK, Kuo YH, Hwang TL, Kuo WL, Lim YP, et al. New Coumarin Derivatives and Other Constituents from the Stem Bark of Zanthoxylum avicennae: Effects on Neutrophil Pro-Inflammatory Responses. Int J Mol Sci. 2015;16:9719-31.

[106] Chen JJ, Chung CY, Hwang TL, Chen JF. Amides and benzenoids from Zanthoxylum ailanthoides with inhibitory activity on superoxide generation and elastase release by neutrophils. J Nat Prod. 2009;72:107-11.

[107] Wang YW, Yang CT, Chen YH, Gong CL, Chen YF, Kuo YH, et al. Inhibitory effects of imperatorin on voltage-gated $\mathrm{K}^{+}$channels and ATP-sensitive $\mathrm{K}^{+}$channels. Pharmacol Rep. 2015;67:134-9.

[108] Chen X, Sun W, Gianaris NG, Riley AM, Cummins TR, Fehrenbacher JC, et al. Furanocoumarins are a novel class of modulators for the transient receptor potential vanilloid type 1 (TRPV1) channel. J Biol Chem. 2014;289:9600-10.

[109] Hua KF, Yang SM, Kao TY, Chang JM, Chen HL, Tsai YJ, et al. Osthole mitigates progressive $\operatorname{IgA}$ nephropathy by inhibiting reactive oxygen species generation and NFkappaB/NLRP3 pathway. PLoS One. 2013;8:e77794.

[110] Li Z, Ji H, Song X, Hu J, Han N, Chen N. Osthole attenuates the development of carrageenan-induced lung inflammation in rats. Int Immunopharmacol. 2014;20:33-6.

[111] Seo EK, Kim KH, Kim MK, Cho MH, Choi E, Kim K, et al. Inhibitors of 5alpha reductase type I in LNCaP cells from the roots of Angelica koreana. Planta Med. 2002;68:162-3. [112] Liu JH, Zschocke S, Reininger E, Bauer R. Inhibitory effects of Angelica pubescens $\mathrm{f}$. biserrata on 5-lipoxygenase and cyclooxygenase. Planta Med. 1998;64:525-9.

[113] Menezes GB, Rezende RM, Pereira-Silva PE, Klein A, Cara DC, Francischi JN. Differential involvement of cyclooxygenase isoforms in neutrophil migration in vivo and in vitro. Eur J Pharmacol. 2008;598:118-22.

[114] Fylaktakidou KC, Hadjipavlou-Litina DJ, Litinas KE, Nicolaides DN. Natural and synthetic coumarin derivatives with anti-inflammatory/ antioxidant activities. Curr Pharm Des. 2004;10:3813-33.

[115] Klotz LO, Hou X, Jacob C. 1,4-naphthoquinones: from oxidative damage to cellular and inter-cellular signaling. Molecules. 2014;19:14902-18. 
[116] Chou TH, Chien SK, Hwang TL, Wei DC, Chen IS, Sung PJ, et al. Orthoquinone and naphthalenone derivatives from Berrya ammonilla and their anti-inflammatory activity. Planta Med. 2012;78:919-25.

[117] Hsu MF, Chang LC, Chen SC, Kuo SC, Lee HY, Lu MC, et al. Blockade of cytosolic phospholipase $\mathrm{A}(2)$ and 5-lipoxygenase activation in neutrophils by a natural isoflavanquinone abruquinone A. Eur J Pharmacol. 2008;598:123-31.

[118] Hsu MF, Chang LC, Huang LJ, Kuo SC, Lee HY, Lu MC, et al. The influence of acetylshikonin, a natural naphthoquinone, on the production of leukotriene B4 and thromboxane A2 in rat neutrophils. Eur J Pharmacol. 2009;607:234-43.

[119] Schaible AM, Traber H, Temml V, Noha SM, Filosa R, Peduto A, et al. Potent inhibition of human 5-lipoxygenase and microsomal prostaglandin $\mathrm{E}(2)$ synthase-1 by the anti-carcinogenic and anti-inflammatory agent embelin. Biochem Pharmacol. 2013;86:476-86.

[120] Chien YC, Lin CH, Chiang MY, Chang HS, Liao CH, Chen IS, et al. Secondary metabolites from the root of Ehretia longiflora and their biological activities. Phytochemistry. 2012;80:50-7.

[121] Zhang J, Chen J, Liang Z, Zhao C. New lignans and their biological activities. Chem Biodivers. 2014;11:1-54.

[122] Chen JJ, Wang TY, Hwang TL. Neolignans, a coumarinolignan, lignan derivatives, and a chromene: anti-inflammatory constituents from Zanthoxylum avicennae. $J$ Nat Prod. 2008;71:212-7.

[123] Chung YM, Lan YH, Hwang TL, Leu YL. Anti-inflammatory and antioxidant components from Hygroryza aristata. Molecules. 2011;16:1917-27.

[124] Kuo WL, Chung CY, Hwang TL, Chen JJ. Biphenyl-type neolignans from Magnolia officinalis and their anti-inflammatory activities. Phytochemistry. 2013;85:153-60.

[125] Lee YM, Hsiao G, Chen HR, Chen YC, Sheu JR, Yen MH. Magnolol reduces myocardial ischemia/reperfusion injury via neutrophil inhibition in rats. Eur J Pharmacol. 2001;422:159-67. [126] Wang JP, Hsu MF, Raung SL, Chang LC, Tsao LT, Lin PL, et al. Inhibition by magnolol of formylmethionyl-leucyl-phenyl alanine-induced respiratory burst in rat neutrophils. J Pharm Pharmacol. 1999;51:285-94.

[127] Wang JP, Chen CC. Magnolol induces cytosolic-free $\mathrm{Ca} 2+$ elevation in rat neutrophils primarily via inositol trisphosphate signalling pathway. Eur J Pharmacol. 1998;352:329-34.

[128] Ai J, Wang X, Nielsen M. Honokiol and magnolol selectively interact with GABAA receptor subtypes in vitro. Pharmacology. 2001;63:34-41.

[129] Liao HR, Chien CR, Chen JJ, Lee TY, Lin SZ, Tseng CP. The anti-inflammatory effect of 2-(4-hydroxy-3-prop-2-enyl-phenyl)-4-prop-2-enyl-phenol by targeting Lyn kinase in human neutrophils. Chem Biol Interact. 2015;236:90-101.

[130] Liou KT, Shen YC, Chen CF, Tsao CM, Tsai SK. The anti-inflammatory effect of honokiol on neutrophils: mechanisms in the inhibition of reactive oxygen species production. Eur J Pharmacol. 2003;475:19-27.

[131] Liou KT, Shen YC, Chen CF, Tsao CM, Tsai SK. Honokiol protects rat brain from focal cerebral ischemia-reperfusion injury by inhibiting neutrophil infiltration and reactive oxygen species production. Brain Res. 2003;992:159-66.

[132] Elakovich SD, Stevens KL. Phytotoxic properties of nordihydroguaiaretic acid, a lignan fromLarrea tridentata (Creosote bush). J Chem Ecol. 1985;11:27-33.

[133] Morikawa M, Fukuchi K, Inoue M, Tsuboi M. Effect of mammalian lignans on fMLPinduced oxidative bursts in human polymorphonuclear leucocytes. J Pharm Pharmacol. 1992;44:859-61. 
[134] Palmer RM, Salmon JA. Comparison of the effects of some compounds on human neutrophil degranulation and leukotriene B4 and thromboxane B2 synthesis. Biochem Pharmacol. 1985;34:1485-90.

[135] Ozaki Y, Ohashi T, Niwa Y. A comparative study on the effects of inhibitors of the lipoxygenase pathway on neutrophil function. Inhibitory effects on neutrophil function may not be attributed to inhibition of the lipoxygenase pathway. Biochem Pharmacol. 1986;35:3481-8.

[136] Salari H, Braquet P, Borgeat P. Comparative effects of indomethacin, acetylenic acids, 15HETE, nordihydroguaiaretic acid and BW755C on the metabolism of arachidonic acid in human leukocytes and platelets. Prostaglandins Leukot Med. 1984;13:53-60.

[137] Schmidt TJ, Heilmann J. Tetrahydrofuran lignans from Illicium floridanum and their activity in a luminol enhanced chemiluminescence assay. Planta Med. 2000;66:749-51.

[138] Liao CH, Chen JJ, Lin JE, Liu CH, Tseng CP, Day YJ. 5-hydroxy-2-(4-hydroxy-3methoxyphenyl)-3,7-dimethoxy-4H-chromen-4-one (MSF-2) suppresses fMLP-mediated respiratory burst in human neutrophils by inhibiting phosphatidylinositol 3-kinase activity. J Cell Physiol. 2011;226:1519-30.

[139] Huang YJ, Chen IS, Tseng CP, Day YJ, Lin YC, Liao CH. (2R,3R)-2-(3',4'dihydroxybenzyl)-3-(3",4"-dimethoxybenzyl)butyrolactone suppresses fMLP-induced superoxide production by inhibiting fMLP-receptor binding in human neutrophils. Biochem Pharmacol. 2008;75:688-97.

[140] Sonestedt E, Wirfalt E. Enterolactone and breast cancer: methodological issues may contribute to conflicting results in observational studies. Nutr Res. 2010;30:667-77.

[141] Chen IH, Du YC, Hwang TL, Chen IF, Lan YH, Yen HF, et al. Anti-inflammatory triterpenoids from the stems of Microtropis fokienensis. Molecules. 2014;19:4608-23.

[142] Sultana N, Saify ZS. Naturally occurring and synthetic agents as potential antiinflammatory and immunomodulants. Antiinflamm Antiallergy Agents Med Chem. 2012;11:319.

[143] Cho JY, Lee TH, Hwang TL, Yang SZ, Chen IS, Chou TH, et al. A new ferulic acid ester, a new ellagic acid derivative, and other constituents from pachycentria formosana: effects on neutrophil pro-inflammatory responses. Chem Biodivers. 2011;8:1709-16.

[144] Lu J, Sun Q, Sugahara K, Sagara Y, Kodama H. Effect of six compounds isolated from rhizome of Anemone raddeana on the superoxide generation in human neutrophil. Biochem Biophys Res Commun. 2001;280:918-22.

[145] Leu YL, Kuo SM, Hwang TL, Chiu ST. The inhibition of superoxide anion generation by neutrophils from Viscum articulactum. Chem Pharm Bull (Tokyo). 2004;52:858-60.

[146] Chan HH, Hwang TL, Reddy MV, Li DT, Qian K, Bastow KF, et al. Bioactive constituents from the roots of Panax japonicus var. major and development of a LC-MS/MS method for distinguishing between natural and artifactual compounds. J Nat Prod. 2011;74:796802.

[147] Chen G, Lu H, Wang C, Yamashita K, Manabe M, Xu S, et al. Effect of five triterpenoid compounds isolated from leaves of Diospyros kaki on stimulus-induced superoxide generation and tyrosyl phosphorylation in human polymorphonuclear leukocytes. Clin Chim Acta. 2002;320:11-6.

[148] Chen X, Yang D, Shen W, Dong HF, Wang JM, Oppenheim JJ, et al. Characterization of chenodeoxycholic acid as an endogenous antagonist of the G-coupled formyl peptide receptors. Inflamm Res. 2000;49:744-55. 
[149] Chen X, Mellon RD, Yang L, Dong H, Oppenheim JJ, Howard OM. Regulatory effects of deoxycholic acid, a component of the anti-inflammatory traditional Chinese medicine Niuhuang, on human leukocyte response to chemoattractants. Biochem Pharmacol. 2002;63:533-41.

[150] Beuers U, Thiel M, Bardenheuer H, Paumgartner G. Tauroursodeoxycholic acid inhibits the cytosolic $\mathrm{Ca}++$ increase in human neutrophils stimulated by formyl-methionyl-leucylphenylalanine. Biochem Biophys Res Commun. 1990;171:1115-21.

[151] Thoren FB, Karlsson J, Dahlgren C, Forsman H. The anionic amphiphile SDS is an antagonist for the human neutrophil formyl peptide receptor 1. Biochem Pharmacol. 2010;80:389-95.

[152] Ferrari C, Macchiarulo A, Costantino G, Pellicciari R. Pharmacophore model for bile acids recognition by the FPR receptor. JComputAided MolDes. 2006;20:295-303.

[153] Makishima M, Okamoto AY, Repa JJ, Tu H, Learned RM, Luk A, et al. Identification of a nuclear receptor for bile acids. Science. 1999;284:1362-5.

[154] Kawamata Y, Fujii R, Hosoya M, Harada M, Yoshida H, Miwa M, et al. A G proteincoupled receptor responsive to bile acids. J Biol Chem. 2003;278:9435-40.

[155] Geyer N, Diszhazi G, Csernoch L, Jona I, Almassy J. Bile acids activate ryanodine receptors in pancreatic acinar cells via a direct allosteric mechanism. Cell Calcium. 2015;58:16070.

[156] Giebeler A, Streetz KL, Soehnlein O, Neumann U, Wang JM, Brandenburg LO. Deficiency of formyl peptide receptor 1 and 2 is associated with increased inflammation and enhanced liver injury after LPS-stimulation. PLoS One. 2014;9:e100522.

[157] Marques PE, Amaral SS, Pires DA, Nogueira LL, Soriani FM, Lima BH, et al. Chemokines and mitochondrial products activate neutrophils to amplify organ injury during mouse acute liver failure. Hepatology. 2012;56:1971-82.

[158] Wei S, He W, Lu J, Wang Z, Yamashita K, Yokoyama M, et al. Effects of five oleanolic acid triterpenoid saponins from the rhizome of Anemone raddeana on stimulus-induced superoxide generation, phosphorylation of proteins and translocation of cytosolic compounds to cell membrane in human neutrophils. Fitoterapia. 2012;83:402-7.

[159] Zhang M, Liu G, Tang S, Song S, Yamashita K, Manabe M, et al. Effect of five triterpenoid compounds from the buds of Aralia elata on stimulus-induced superoxide generation, tyrosyl phosphorylation and translocation of cytosolic compounds to the cell membrane in human neutrophils. Planta Med. 2006;72:1216-22.

[160] Huang HC, Lin MK, Hwang SY, Hwang TL, Kuo YH, Chang CI, et al. Two antiinflammatory steroidal saponins from Dracaena angustifolia Roxb. Molecules. 2013;18:8752-63. [161] Hwang TL, Wang CC, Kuo YH, Huang HC, Wu YC, Kuo LM, et al. The hederagenin saponin SMG-1 is a natural FMLP receptor inhibitor that suppresses human neutrophil activation. Biochem Pharmacol. 2010;80:1190-200.

[162] Chao CH, Cheng JC, Hwang TL, Shen DY, Wu TS. Trinorditerpenes from the roots of Flueggea virosa. Bioorg Med Chem Lett. 2014;24:447-9.

[163] Chang HL, Chang FR, Chen JS, Wang HP, Wu YH, Wang CC, et al. Inhibitory effects of 16-hydroxycleroda-3,13(14)E-dien-15-oic acid on superoxide anion and elastase release in human neutrophils through multiple mechanisms. Eur J Pharmacol. 2008;586:332-9.

[164] Yang YL, Chang FR, Hwang TL, Chang WT, Wu YC. Inhibitory effects of ent-kauranes from the stems of Annona squamosa on superoxide anion generation by human neutrophils. Planta Med. 2004;70:256-8. 
[165] Yeh SH, Chang FR, Wu YC, Yang YL, Zhuo SK, Hwang TL. An anti-inflammatory entkaurane from the stems of Annona squamosa that inhibits various human neutrophil functions. Planta Med. 2005;71:904-9.

[166] Chang FR, Hwang TL, Yang YL, Li CE, Wu CC, Issa HH, et al. Anti-inflammatory and cytotoxic diterpenes from formosan Polyalthia longifolia var. pendula. Planta Med. 2006;72:1344-7.

[167] Lin KH, Tseng YJ, Chen BW, Hwang TL, Chen HY, Dai CF, et al. Tortuosenes A and B, new diterpenoid metabolites from the Formosan soft coral Sarcophyton tortuosum. Org Lett. 2014;16:1314-7.

[168] Huang TZ, Chen BW, Huang CY, Hwang TL, Dai CF, Sheu JH. Eunicellin-based diterpenoids, hirsutalins N-R, from the formosan soft coral Cladiella hirsuta. Mar Drugs. 2014;12:2446-57.

[169] Huang TZ, Chen BW, Huang CY, Hwang TL, Uvarani C, Dai CF, et al. Eunicellin-Based Diterpenoids, Hirsutalins S-V, from the Formosan Soft Coral Cladiella hirsuta. Mar Drugs. 2015;13:2757-69.

[170] Liaw CC, Cheng YB, Lin YS, Kuo YH, Hwang TL, Shen YC. New briarane diterpenoids from Taiwanese soft coral Briareum violacea. Mar Drugs. 2014;12:4677-92.

[171] Lee YN, Tai CJ, Hwang TL, Sheu JH. Krempfielins N-P, New anti-inflammatory eunicellins from a Taiwanese soft coral Cladiella krempfi. Mar Drugs. 2014;12:1148-56.

[172] Lee YN, Tai CJ, Hwang TL, Sheu JH. Krempfielins J-M, new eunicellin-based diterpenoids from the soft coral Cladiella krempfi. Mar Drugs. 2013;11:2741-50.

[173] Liaw CC, Lin YC, Lin YS, Chen CH, Hwang TL, Shen YC. Four new briarane diterpenoids from Taiwanese gorgonian Junceella fragilis. Mar Drugs. 2013;11:2042-53.

[174] Chang JY, Liaw CC, Fazary AE, Hwang TL, Shen YC. New Briarane diterpenoids from the gorgonian coral Junceella juncea. Mar Drugs. 2012;10:1321-30.

[175] Chang JY, Fazary AE, Lin YC, Hwang TL, Shen YC. New verticillane diterpenoids from Cespitularia taeniata. Chem Biodivers. 2012;9:654-61.

[176] Liaw CC, Kuo YH, Lin YS, Hwang TL, Shen YC. Frajunolides L-O, four new 8Hydroxybriarane diterpenoids from the Gorgonian Junceella fragilis. Mar Drugs. 2011;9:147786.

[177] Lin MC, Chen BW, Huang CY, Dai CF, Hwang TL, Sheu JH. Eunicellin-based diterpenoids from the Formosan soft coral Klyxum molle with inhibitory activity on superoxide generation and elastase release by neutrophils. J Nat Prod. 2013;76:1661-7.

[178] Arakawa NS, Schorr K, Ambrosio SR, Merfort I, Da Costa FB. Further sesquiterpene lactones from Viguiera robusta and the potential anti-inflammatory activity of a heliangolide: inhibition of human neutrophil elastase release. Z Naturforsch C. 2008;63:533-8.

[179] Liou BJ, Chang HS, Wang GJ, Chiang MY, Liao CH, Lin CH, et al. Secondary metabolites from the leaves of Neolitsea hiiranensis and the anti-inflammatory activity of some of them. Phytochemistry. 2011;72:415-22.

[180] Chen KS, Hsieh PW, Hwang TL, Chang FR, Wu YC. Anti-inflammatory furanogermacrane sesquiterpenes from Neolitsea parvigemma. Nat Prod Res. 2005;19:283-6.

[181] Stefani R, Schorr K, Tureta JM, Vichnewski W, Merfort I, da Costa FB. Sesquiterpene lactones from Dimerostemma species (Asteraceae) and in vitro potential anti-inflammatory activities. Z Naturforsch C. 2006;61:647-52.

[182] Ghantous A, Gali-Muhtasib H, Vuorela H, Saliba NA, Darwiche N. What made sesquiterpene lactones reach cancer clinical trials? Drug Discov Today. 2010;15:668-78. 
[183] Chen JJ, Ting CW, Hwang TL, Chen IS. Benzophenone derivatives from the fruits of Garcinia multiflora and their anti-inflammatory activity. J Nat Prod. 2009;72:253-8.

[184] Ting CW, Hwang TL, Chen IS, Yen MH, Chen JJ. A new benzoylphloroglucinol derivative with an adamantyl skeleton and other constituents from Garcinia multiflora: effects on neutrophil pro-inflammatory responses. Chem Biodivers. 2012;9:99-105.

[185] Ting CW, Hwang TL, Chen IS, Cheng MJ, Sung PJ, Yen MH, et al. Garcimultiflorone G, a novel benzoylphloroglucinol derivative from Garcinia multiflora with inhibitory activity on neutrophil pro-inflammatory responses. Chem Biodivers. 2014;11:819-24.

[186] Weng JR, Lin CN, Tsao LT, Wang JP. Terpenoids with a new skeleton and novel triterpenoids with anti-inflammatory effects from Garcinia subelliptica. Chemistry. 2003;9:55207.

[187] Weng JR, Lin CN, Tsao LT, Wang JP. Novel and anti-inflammatory constituents of Garcinia subelliptica. Chemistry. 2003;9:1958-63.

[188] Chou TH, Chen IS, Hwang TL, Wang TC, Lee TH, Cheng LY, et al. Phthalides from Pittosporum illicioides var. illicioides with inhibitory activity on superoxide generation and elastase release by neutrophils. J Nat Prod. 2008;71:1692-5.

[189] Chung YM, Chang FR, Tseng TF, Hwang TL, Chen LC, Wu SF, et al. A novel alkaloid, aristopyridinone $\mathrm{A}$ and anti-inflammatory phenanthrenes isolated from Aristolochia manshuriensis. Bioorg Med Chem Lett. 2011;21:1792-4.

[190] Wu SF, Hwang TL, Chen SL, Wu CC, Ohkoshi E, Lee KH, et al. Bioactive components from the heartwood of Pterocarpus santalinus. Bioorg Med Chem Lett. 2011;21:5630-2.

[191] Wang TY, Wu JB, Hwang TL, Kuo YH, Chen JJ. A new quinolone and other constituents from the fruits of Tetradium ruticarpum: effects on neutrophil pro-inflammatory responses. Chem Biodivers. 2010;7:1828-34.

[192] Moon TC, Murakami M, Kudo I, Son KH, Kim HP, Kang SS, et al. A new class of COX-2 inhibitor, rutaecarpine from Evodia rutaecarpa. Inflamm Res. 1999;48:621-5.

[193] Lee SH, Son JK, Jeong BS, Jeong TC, Chang HW, Lee ES, et al. Progress in the studies on rutaecarpine. Molecules. 2008;13:272-300.

[194] Jia S, Hu C. Pharmacological effects of rutaecarpine as a cardiovascular protective agent. Molecules. 2010;15:1873-81.

[195] Chen JJ, Tsai YC, Hwang TL, Wang TC. Thymol, benzofuranoid, and phenylpropanoid derivatives: anti-inflammatory constituents from Eupatorium cannabinum. J Nat Prod. 2011;74:1021-7.

[196] Schepetkin IA, Kushnarenko SV, Ozek G, Kirpotina LN, Utegenova GA, Kotukhov YA, et al. Inhibition of Human Neutrophil Responses by the Essential Oil of Artemisia kotuchovii and Its Constituents. J Agric Food Chem. 2015;63:4999-5007.

[197] Rios JJ, Fernandez-Garcia E, Minguez-Mosquera MI, Perez-Galvez A. Description of volatile compounds generated by the degradation of carotenoids in paprika, tomato and marigold oleoresins. Food Chem. 2008;106:1145-53.

[198] Hwang TL, Leu YL, Kao SH, Tang MC, Chang HL. Viscolin, a new chalcone from Viscum coloratum, inhibits human neutrophil superoxide anion and elastase release via a cAMPdependent pathway. Free Radic Biol Med. 2006;41:1433-41.

[199] Wu YC, Sureshbabu M, Fang YC, Wu YH, Lan YH, Chang FR, et al. Potent inhibition of human neutrophil activations by bractelactone, a novel chalcone from Fissistigma bracteolatum. Toxicol Appl Pharmacol. 2013;266:399-407.

[200] Wang JP, Tsao LT, Raung SL, Lin CN. Investigation of the inhibitory effect of broussochalcone A on respiratory burst in neutrophils. Eur J Pharmacol. 1997;320:201-8. 
[201] Zhang FJ, Yang JY, Mou YH, Sun BS, Ping YF, Wang JM, et al. Inhibition of U-87 human glioblastoma cell proliferation and formyl peptide receptor function by oligomer procyanidins (F2) isolated from grape seeds. Chem Biol Interact. 2009;179:419-29.

[202] Yang J, Wang Q, Zhao R, Sun B, Wang L, Hou Y, et al. Identification of oligomer proanthocyanidins (F2) isolated from grape seeds as a formyl peptide receptor 1 partial agonist. Int Immunopharmacol. 2013;15:756-63.

[203] Fang HY, Chokkalingam U, Chiou SF, Hwang TL, Chen SL, Wang WL, et al. Bioactive chemical constituents from the brown alga Homoeostrichus formosana. Int $\mathrm{J}$ Mol Sci. 2015;16:736-46.

[204] Chen BW, Uvarani C, Huang CY, Hwang TL, Dai CF, Sheu JH. New anti-inflammatory tocopherol-derived metabolites from the Taiwanese soft coral Cladiella hirsuta. Bioorg Med Chem Lett. 2015;25:92-5.

[205] Samiulla DS, Vaidyanathan VV, Arun PC, Balan G, Blaze M, Bondre S, et al. Rational selection of structurally diverse natural product scaffolds with favorable ADME properties for drug discovery. Mol Divers. 2005;9:131-9.

[206] Low CM, Vinter JG. Rationalizing the activities of diverse cholecystokinin 2 receptor antagonists using molecular field points. J Med Chem. 2008;51:565-73.

[207] Cheeseright T, Mackey M, Rose S, Vinter A. Molecular field extrema as descriptors of biological activity: definition and validation. J Chem Inf Model. 2006;46:665-76.

[208] Cheeseright TJ, Mackey MD, Scoffin RA. High content pharmacophores from molecular fields: a biologically relevant method for comparing and understanding ligands. Curr Comput Aided Drug Des. 2011;7:190-205.

[209] Unitt J, Fagura M, Phillips T, King S, Perry M, Morley A, et al. Discovery of small molecule human FPR1 receptor antagonists. Bioorg Med Chem Lett. 2011;21:2991-7.

[210] Khlebnikov AI, Schepetkin IA, Kirpotina LN, Brive L, Dahlgren C, Jutila MA, et al. Molecular docking of 2-(benzimidazol-2-ylthio)-N-phenylacetamide-derived small-molecule agonists of human formyl peptide receptor 1. J Mol Model. 2012;18:2831-43.

[211] Koeberle A, Northoff H, Werz O. Identification of 5-lipoxygenase and microsomal prostaglandin E2 synthase-1 as functional targets of the anti-inflammatory and anti-carcinogenic garcinol. Biochem Pharmacol. 2009;77:1513-21.

[212] Feisst C, Pergola C, Rakonjac M, Rossi A, Koeberle A, Dodt G, et al. Hyperforin is a novel type of 5-lipoxygenase inhibitor with high efficacy in vivo. Cell Mol Life Sci. 2009;66:2759-71.

[213] van der Westhuizen ET, Valant C, Sexton PM, Christopoulos A. Endogenous allosteric modulators of G protein-coupled receptors. J Pharmacol Exp Ther. 2015;353:246-60.

[214] Kasai RS, Suzuki KG, Prossnitz ER, Koyama-Honda I, Nakada C, Fujiwara TK, et al. Full characterization of GPCR monomer-dimer dynamic equilibrium by single molecule imaging. $\mathrm{J}$ Cell Biol. 2011;192:463-80. 
Table 1. Structures of selected natural compounds and their synthetic derivatives that inhibited $f$ MLF-induced functional responses in neutrophils.

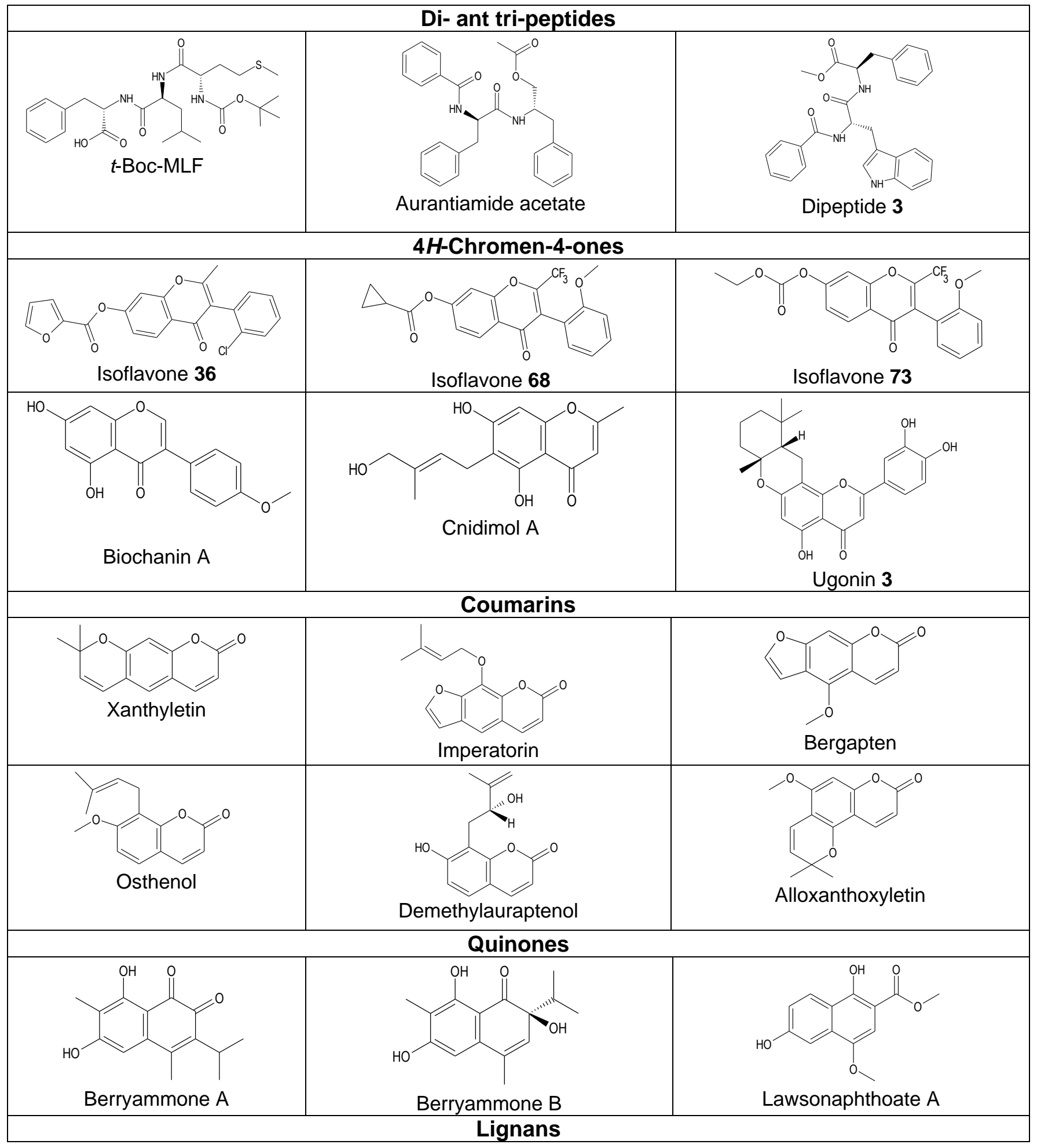




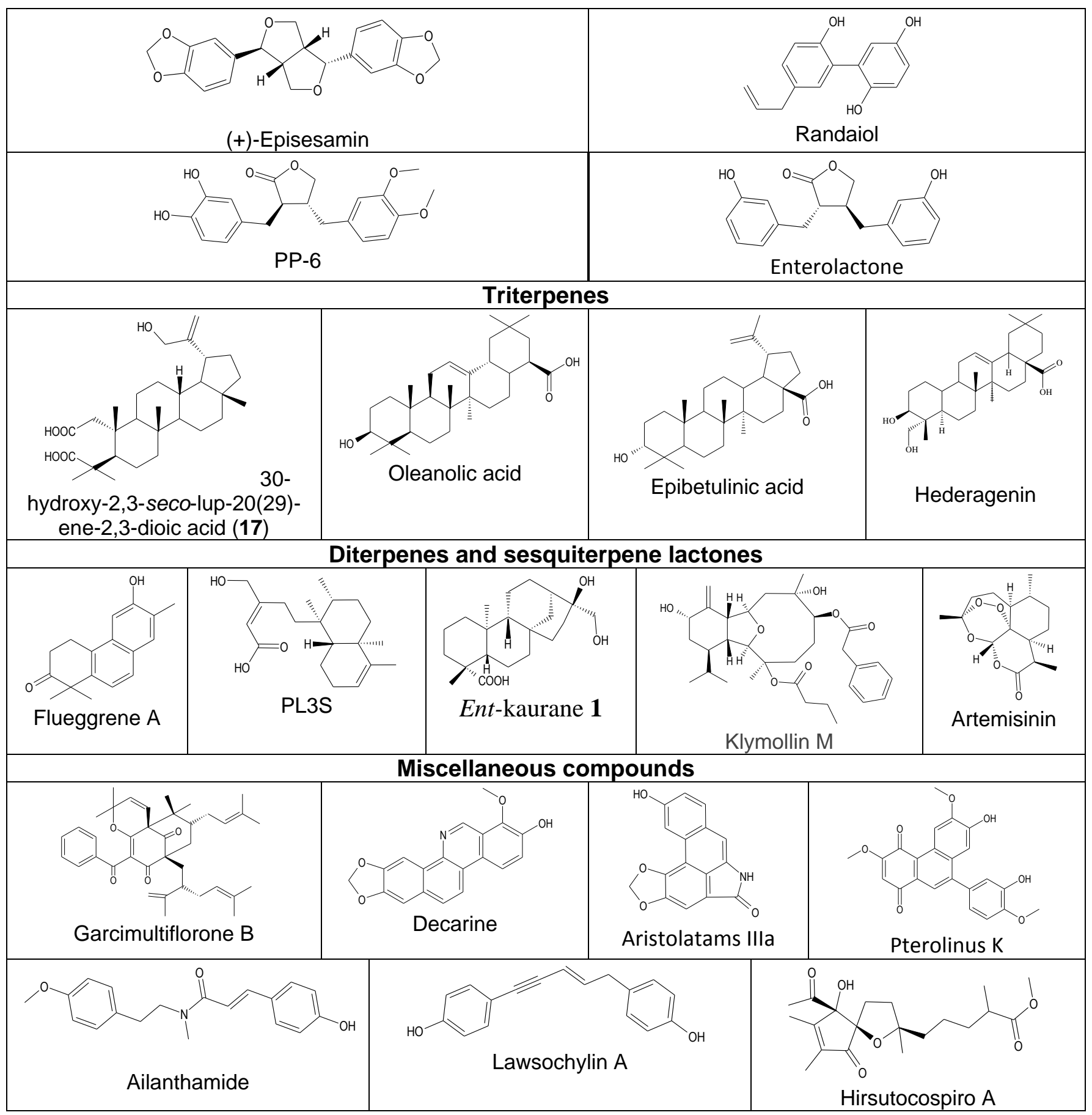




\begin{tabular}{|c|c|c|}
\hline Compound & fMLF-induced Responses Inhibited in Neutrophils & References \\
\hline$t$-Boc-MLF & FPR1 binding, $\mathrm{O}_{2}$ production, cell adhesion & {$[29,51]$} \\
\hline Aurantiamide acetate & $\mathrm{O}_{2}^{-}$production & [60] \\
\hline Dipeptide $\mathbf{3}$ & $\mathrm{O}_{2}^{-}$production, $\mathrm{HNE}$ release & [62] \\
\hline Isoflavone 36 & $\mathrm{Ca}^{2+}$ flux, FPR1 binding & [79] \\
\hline Isoflavone 68 & $\mathrm{Ca}^{2+}$ flux, FPR1 binding & [79] \\
\hline Isoflavone 73 & $\mathrm{Ca}^{2+}$ flux, FPR1 binding & [79] \\
\hline Biochanin A & $\mathrm{Ca}^{2+}$ flux, FPR1 binding & [79] \\
\hline Cnidimol A & $\mathrm{O}_{2}-$ production, HNE release & [94] \\
\hline Ugonin 3 & $\mathrm{O}_{2} \cdot$ production, HNE release & [95] \\
\hline Xanthyletin & $\mathrm{O}_{2} \cdot$ Production, HNE release & {$[104,106]$} \\
\hline Imperatorin & $\mathrm{O}_{2}^{-}$production & [103] \\
\hline Bergapten & $\mathrm{O}_{2}$ production, $\mathrm{HNE}$ release & [94] \\
\hline Osthenol & $\mathrm{O}_{2}-$ production, HNE release & [94] \\
\hline Demethylauraptenol & $\mathrm{O}_{2}^{-}$production, $\mathrm{HNE}$ release & [94] \\
\hline Alloxanthoxyletin & $\mathrm{O}_{2}-$ production, HNE release & [105] \\
\hline Berryammone $\mathrm{A}$ & $\mathrm{O}_{2}-$ production, $\mathrm{HNE}$ release & [116] \\
\hline Berryammone B & $\mathrm{O}_{2}-$ production, $\mathrm{HNE}$ release & [116] \\
\hline Lawsonaphthoate A & $\mathrm{O}_{2}^{-}$production, HNE release & [73] \\
\hline (+)-Episesamin & $\mathrm{O}_{2}^{-}$production, HNE release & [104] \\
\hline Randaiol & $\mathrm{O}_{2}^{-}$production and $\mathrm{HNE}$ release & [124] \\
\hline Lignan PP-6 & $\begin{array}{l}\text { FPR1 binding, } \mathrm{Ca}^{2+} \text { flux, } \mathrm{O}_{2} \text { production, } \\
\text { phosphorylation of ERK } 1 / 2 \text {, Akt, and p38 }\end{array}$ & [139] \\
\hline Triterpene 17 & $\mathrm{O}_{2}$ production, $\mathrm{HNE}$ release & [141] \\
\hline Oleanolic acid & $\mathrm{O}_{2}^{-}$production, HNE release & [143-146] \\
\hline Epibetulinic acid & $\mathrm{O}_{2}^{-}$production & [143] \\
\hline Flueggrene $\mathrm{A}$ & $\mathrm{O}_{2}^{-}$production, $\mathrm{HNE}$ release & [162] \\
\hline Diterpene PL3S & $\mathrm{O}_{2}-$ production, $\mathrm{HNE}$ release & [163] \\
\hline Ent-kaurane 1 & $\mathrm{O}_{2}^{-}$production, $\mathrm{HNE}$ release, $\mathrm{Ca}^{2+}$ flux & {$[164,165]$} \\
\hline Klymollin M & $\mathrm{O}_{2}-$ production, HNE release & [177] \\
\hline Garcimultiflorone B & $\mathrm{O}_{2}^{-}$production, $\mathrm{HNE}$ release & [183] \\
\hline Decarine & $\mathrm{O}_{2}-$ production, HNE release & {$[104,106]$} \\
\hline Aristolatams IIIa & $\mathrm{O}_{2}^{-}$production, HNE release & [189] \\
\hline Pterolinus K & $\mathrm{O}_{2} \cdot$ production, HNE release & [190] \\
\hline Ailanthamide & $\mathrm{O}_{2}-$ production, HNE release & [106] \\
\hline Lawsochylin A & $\mathrm{O}_{2} \cdot$ production, HNE release & [73] \\
\hline Hirsutocospiro A & $\mathrm{O}_{2}^{-}$production, $\mathrm{HNE}$ release & [204] \\
\hline
\end{tabular}

Compound numbers for dipeptide 3 , isoflavones $(\mathbf{3 6}, \mathbf{6 8}$, and $\mathbf{7 3})$, ugonin 3 , triterpene 17 , and ent-kaurane 1 are as designated in previous reports [62, 79, 95, 141, 165]. 
Table 2. Effects of selected natural compounds on $\mathrm{Ca}^{2+}$ mobilization in human neutrophils and FPR1 transfected HL-60 cells.

\begin{tabular}{|c|c|c|c|c|}
\hline \multirow{2}{*}{ Compound } & \multicolumn{2}{|c|}{ Human Neutrophils } & \multicolumn{2}{c|}{ FPR1 HL-60 } \\
\cline { 2 - 5 } & $\begin{array}{c}\text { Activation } \\
\left(\mathbf{E C}_{50}, \boldsymbol{\mu M}\right)\end{array}$ & $\begin{array}{c}\text { Inhibition } \\
\left(\mathbf{I C}_{50}, \boldsymbol{\mu M}\right)\end{array}$ & $\begin{array}{c}\text { Activation } \\
\left(\mathbf{E C}_{50}, \boldsymbol{\mu M}\right)\end{array}$ & $\begin{array}{c}\text { Inhibition } \\
\left(\mathbf{I} \mathbf{C}_{50}, \boldsymbol{\mu M}\right)\end{array}$ \\
\hline Imperatorin & $31.1 \pm 3.6$ & $31.2 \pm 2.8$ & $50.9 \pm 4.7$ & $33.9 \pm 4.2$ \\
\hline Bergapten & N.A. & N.A. & N.A. & N.A. \\
\hline (+)-Episesamin & $38.1 \pm 4.2$ & $30.4 \pm 2.6$ & $54.8 \pm 5.2$ & $45.4 \pm 4.9$ \\
\hline Enterolactone & N.A. & N.A. & N.A. & N.A. \\
\hline Oleanolic acid & N.A. & $1.5 \pm 0.18$ & N.A. & $14.5 \pm 3.3$ \\
\hline Hederagenin & N.A. & $11.5 \pm 1.4$ & N.A. & $10.1 \pm 2.6$ \\
\hline Chenodeoxycholic acid (CDCA) & $49.5 \pm 5.1$ & $21.4 \pm 1.6$ & $40.3 \pm 4.5$ & $19.9 \pm 3.7$ \\
\hline Deoxycholic acid (DCA) & $49.0 \pm 5.4$ & $32.6 \pm 3.3$ & $40.9 \pm 5.5$ & $20.8 \pm 2.9$ \\
\hline Artemisinin & N.A. & N.A. & N.A. & N.A. \\
\hline
\end{tabular}

Imperatorin, bergapten, (+)-episesamin, and hederagenin were from Toronto Research Chemicals (Toronto, Canada); enterolactone was from Cayman Chemical (Ann Arbor, MI); chenodeoxycholic acid was from Chem-Impex (Wood Dale, IL); deoxycholic acid was from Alfa Aesar (Ward Hill, MA); oleanolic acid was from Seleckchem (Houston, TX); and artemisinin was from Biotrend Chemicals (Zurich, Switzerland). Compounds were evaluated for their ability to directly activate or inhibit $f$ MLF-induced $\mathrm{Ca}^{2+}$ flux in human neutrophils and FPR1 transfected HL-60 cells. Changes in intracellular $\mathrm{Ca}^{2+}$ were measured with a FlexStation II scanning fluorometer, as described previously [79]. For evaluation of direct agonist activity, compounds of interest were added from a source plate just before plate reading. Antagonist activity and selectivity were evaluated after 30 min pretreatment with test compounds at room temperature, followed by addition of $5 \mathrm{nM} f \mathrm{MLF}$. N.A., no activity was betobserved at the highest tested concentration $(55 \mu \mathrm{M})$. 
Table 3. Biological activity of selected natural compounds and their ability to contribute to a high-quality common 4-molecule pharmacophore template of orthosteric FPR1 antagonists.

\begin{tabular}{|c|c|c|c|c|c|}
\hline \multirow{3}{*}{ Compound } & \multicolumn{3}{|c|}{ Inhibitory effect on fMLF-induced } & \multirow{3}{*}{$\mu^{\mathrm{a}}$} & \multirow{3}{*}{$\begin{array}{c}\text { Predicted } \\
\text { FPR1 binding }\end{array}$} \\
\hline & $\begin{array}{c}\mathrm{O}_{2}^{-} \\
\text {production }\end{array}$ & $\begin{array}{c}\text { HNE } \\
\text { release }\end{array}$ & $\mathrm{Ca}^{2+}$ flux & & \\
\hline & \multicolumn{3}{|c|}{$\mathrm{IC}_{50}(\mu \mathrm{M})$} & & \\
\hline Aurantiamide acetate & $\sim 15.0$ & n.d. & n.d. & 0.05 & No \\
\hline Cnidimol A & 13.4 & 11.6 & n.d. & 0.04 & Yes \\
\hline Ugonin 3 & 3.8 & 2.5 & n.d. & 0.06 & No \\
\hline Xanthyletin & 18.4 & 24.1 & n.d. & 0.06 & No \\
\hline Demethylauraptenol & 2.2 & 17.9 & n.d. & 0.06 & No \\
\hline Berryammone $\mathrm{A}$ & 3.2 & 3.8 & n.d. & 0.05 & No \\
\hline Berryammone $\mathrm{B}$ & 1.7 & 1.8 & n.d. & 0.05 & No \\
\hline Lawsonaphthoate A & 8.5 & 20.6 & n.d. & 0.05 & No \\
\hline Randaiol & 1.6 & 6.9 & n.d. & 0.05 & No \\
\hline Lignan PP-6 & 0.3 & n.d. & $<10$ & 0.03 & Yes \\
\hline Triterpene 17 & 0.12 & 2.2 & n.d. & 0.05 & No \\
\hline Oleanolic acid & 1.4 & 0.75 & 1.5 & 0.06 & No \\
\hline Hederagenin & n.d. & n.d. & 11.5 & 0.06 & No \\
\hline Flueggrene $\mathrm{A}$ & 4.4 & 4.3 & n.d. & 0.05 & No \\
\hline Diterpene PL3S & $\sim 3.0$ & $\sim 3.0$ & n.d. & 0.04 & Yes \\
\hline Ent-kaurane 1 & 4.0 & 12.5 & $\sim 30.0$ & 0.06 & No \\
\hline Klymollin M & 3.1 & 2.9 & n.d. & 0.06 & No \\
\hline Garcimultiflorone B & 0.11 & 0.14 & n.d. & 0.03 & Yes \\
\hline Decarine & 4.1 & 6.3 & n.d. & 0.05 & No \\
\hline Aristolatams IIla & 0.43 & 0.72 & n.d. & 0.06 & No \\
\hline Pterolinus K & 0.99 & 4.2 & n.d. & 0.05 & No \\
\hline Ailanthamide & 12.0 & 13.5 & n.d. & 0.05 & No \\
\hline Lawsochylin A & 7.2 & 6.4 & n.d. & 0.06 & No \\
\hline Hirsutocospiro A & 4.1 & 3.7 & n.d. & 0.05 & No \\
\hline
\end{tabular}

${ }^{a}$ Maximum score variation per molecule pairs, which is an adjustable parameter of the template construction algorithm in the FieldTemplater program. Lower values of $\mu$ indicate templates of higher quality. ${ }^{\mathrm{b}}$ If $\mu \leq 0.04$ for a common 4-molecule FPR1 template, the compound was predicted to bind FPR1. n.d., no data. 
Table 4. H-bonding centers of FPR1 and docked natural molecules, as well as energies of Hbond interactions between the indicated centers for the best predicted docking poses.

\begin{tabular}{|c|c|c|c|c|c|c|}
\hline \multirow{2}{*}{ Compound } & \multirow{2}{*}{$\begin{array}{c}\text { Number of } \\
\text { H-bonds }\end{array}$} & \multicolumn{2}{|c|}{ Ligand } & \multicolumn{2}{|c|}{ FPR1 residues } & \multirow{2}{*}{$\begin{array}{c}\text { Energy } \\
(\mathrm{kcal} / \mathrm{mol})\end{array}$} \\
\hline & & Center & Type & Center & Type & \\
\hline \multirow{3}{*}{ PP-6 } & \multirow{3}{*}{3} & $m-\mathrm{OH}$ & $\begin{array}{l}\text { Acceptor / } \\
\text { Donor }\end{array}$ & $\begin{array}{c}\text { Phenolic } \mathrm{OH} \text { in } \\
\text { Tyr257 }\end{array}$ & $\begin{array}{l}\text { Donor / } \\
\text { Acceptor }\end{array}$ & 1.79 \\
\hline & & $p-\mathrm{OCH}_{3}$ & Acceptor & $\begin{array}{l}\text { Terminal } \\
\text { nitrogen in } \\
\text { Arg205 }\end{array}$ & Donor & 2.06 \\
\hline & & $m-\mathrm{OCH}_{3}$ & Acceptor & $\begin{array}{l}\text { Terminal } \\
\text { nitrogen in } \\
\text { Arg205 }\end{array}$ & Donor & 1.18 \\
\hline \multirow{2}{*}{ Cnidimol A } & \multirow{2}{*}{2} & $\mathrm{CH}_{2} \mathrm{OH}$ & Donor & $\begin{array}{l}\text { COOH in } \\
\text { Asp106 }\end{array}$ & Acceptor & 2.37 \\
\hline & & $\begin{array}{c}\text { Endocyclic } \\
\text { oxygen }\end{array}$ & Acceptor & $\mathrm{OH}$ in Thr265 & Donor & 2.24 \\
\hline $\begin{array}{c}\text { Garcimultiflorone } \\
\text { B }\end{array}$ & 1 & $\begin{array}{c}\text { Endocyclic } \\
\text { oxygen }\end{array}$ & Acceptor & $\mathrm{OH}$ in Thr265 & Donor & 2.50 \\
\hline PL3S & 1 & $\mathrm{CH}_{2} \mathrm{OH}$ & $\begin{array}{c}\text { Acceptor / } \\
\text { Donor }\end{array}$ & OH in Thr265 & $\begin{array}{c}\text { Donor / } \\
\text { Acceptor }\end{array}$ & 2.41 \\
\hline
\end{tabular}

Molecular modeling was performed using the Leu101 FPR1 variant. 


\section{Figure legends}

Figure 1. Summary of $f$ MLF-induced signaling events in human neutrophils. Upon $f$ MLF binding, trimeric $\mathrm{G}$ proteins are uncoupled from formyl peptide receptor 1 (FPR1), and a series of signal transductions events ensue, resulting in neutrophil degranulation, including release of human neutrophil elastase (HNE), activation of the NADPH oxidase to produce reactive oxygen species (ROS), such as superoxide anion $\left(\mathrm{O}_{2}^{-}\right)$, and chemotaxis. FPR1 activation can be blocked by either orthosteric or allosteric antagonists. The second messengers resulting from FPR1 activation regulate three main intracellular kinase pathways, including phosphatidylinositol-3kinase (PI3K), protein kinase $\mathrm{C}(\mathrm{PKC})$, and mitogen-activated protein (MAP) kinases p38/extracellular signal related kinases 1 and 2 (ERK 1/2), leading to the array of functional responses listed. In addition, PKC-independent pathways can be activated through the Srcrelated tyrosine kinase, Lyn. Rho GTPase pathways also play key roles in regulating a variety of neutrophil functional responses. PKC-independent pathways can be activated through the Srcrelated tyrosine kinase, Lyn. Activation of protein kinase $\mathrm{C}(\mathrm{PKC})$ and mitogen-activated protein kinase (MAPK) and elevation in intracellular $\mathrm{Ca}^{2+}\left(\left[\mathrm{Ca}^{2+}\right]_{\mathrm{i}}\right)$ also results in the activation phospholipase $\mathrm{A}_{2}\left(\mathrm{PLA}_{2}\right)$, leading to arachidonic acid (AA) release. AA is metabolized by 5lipoxygenase (5-LO) and cyclooxygenase (COX), and products of this metabolism [hydroxyeicosatetraenoic acid (HETE), leukotriene $\mathrm{B}_{4}\left(\mathrm{LTB}_{4}\right)$, prostaglandins (PGs), etc.] can act in an autocrine manner. As discussed in the text, various natural compounds can interfere with receptor binding and downstream intracellular signaling events.

Figure 2. Docking poses of cyclosporine $\mathrm{H}$ and $f \mathrm{MLF}$ into the FPR1 ligand binding site. Docking poses for CsH (green) and fMLF (yellow) were determined using Molegro software for 
the Val101 (Panel A) and Leu101 (Panel B) FPR1 variants. Briefly, the PDB structure of a rhodopsin-based homology model of FPR1 was imported into the Molegro program. To perform "mutation," Leu101 was changed into Val101, and the latter was optimized using a built-in module of the program. The search space was defined as a sphere of $11 \AA$, as described previously [210]. Side chains of 34 residues inside this sphere were treated as flexible during docking. $\mathrm{CsH}$ and $f \mathrm{MLF}$ structures were prepared using the HyperChem 7 package and optimized with the MM+ force field. Arrows indicate channel $\mathbf{C}$ (region designated as previously reported [210]). Surface coloring is based on electrostatic properties, where negatively and positively charged areas are shown in red and blue, respectively.

Figure 3. Molecular docking of natural compounds with $\mu \leq 0.04$ into the FPR1 ligand binding site. Panel A. Overlaid docking poses of PP-6 (light-blue), cnidimol A (pink), PL3S (red), garcimultiflorone B (green), and fMLF (yellow) into the Leu101 FPR1 variant. Structures of the docked compounds were prepared using the HyperChem 7 package and optimized with the MM+ force field. Arrows indicate: channel A; curved cavity $\mathbf{B}$ located behind the blue-colored ledge; channel $\mathbf{C}$; and "bottom" $\mathbf{D}$ of the binding site between channels $\mathbf{A}$ and $\mathbf{C}$ (regions designated as previously reported [210]). Surface coloring is based on electrostatic properties, where negatively and positively charged areas are shown in red and blue, respectively. Panel B. H-bonding of PP-6 in the FPR1 ligand binding site. Residues within $6 \AA$ of the docking pose are shown. H-bonds are indicated with dashed lines. 